\title{
¡Ay Negrita, sálvanos!
}

\author{
Licda. Ana Ligia Rovira Ugalde*
}

\begin{abstract}
RESUMEN
La fe en la Virgen de los Ángeles se abriga en el sentimiento popular, a partir de la confirmación de fe establecida desde las encíclicas papales y la referencia a María en los textos sagrados. La fe no es solo mero sentimiento sino una plasmación que confirma la grandeza de la Virgen, producto de sus actos y de su vida como tal. El texto, de tal forma, plantea el papel importante de María como mediadora y como madre elegida para Jesús. Se analiza lo que significa la Virgen como culto, como objeto de veneración en el pueblo y en el imaginario en general.
\end{abstract}

Palabras clave: Negrita, promesa, gracia, fe, religiosidad

\section{ABSTRACT}

Negrita Ay Save us! Faith in the "Virgen de los Angeles" (Angels Virgin) is cherished in the popular sentiment, from the confirmation of the established faith from the papal' encyclicals and the reference to Mary in the sacred texts. Faith is not just a feeling but a form which confirms the greatness of the Virgin, as a product of her actions and her life as such. The text so raises the important role of Mary as mediator and as a chosen mother for Jesus. It analyzes what signifies the Virgin as a cult, as an object of worship in the populace and imagination in general.

Key words: "Negrita", promise, grace, faith, religiousness. A la memoria de mi amiga Luz (la Monjita),
amiga de la Luz y de la Misericordia.

* 1. Bachiller en Filología, Universidad de Costa Rica.

2. Bachiller de Enseñanza en Lengua y Literatura, Universidad Nacional.

3. Licenciada en Pedagogía de la Comunicación, Universidad Nacional.

4. Profesora de Teología y Comunicación, en la Escuela Ecuménica de Ciencias de la Religión y el Instituto Teológico de América Central (I.T.A.C.).

5. Fundadora de la Cátedra de Teología de la Mujer, Emilia Prieto. 


\section{Introducción}

¿Para quiénes es este mensaje? Para ustedes, hermanos y hermanas seguidores de la devoción de la Virgen de los Ángeles; para ustedes que aman, y que por ese amor intuyen que amar es comprometerse en la tarea de mejorar el mundo y de crecer todos los días en sabiduría. Para ustedes que se esmeran, desde la cotidianidad y la sencillez, por crear la convivencia humana verdadera, la unión y la fraternidad.

Para ustedes que hacen solidaridad desde el corazón porque sienten como propio el dolor de los y las demás. Para ustedes, peregrinos y peregrinas, que creen que el sacrificio es querido por Dios e ignoran que su voluntad es que seamos felices. Para ustedes que ponen su confianza en María, aunque ignoren la doctrina.... En fin para usted que por casualidad ha llegado a estas páginas.

¿Por qué he escrito este ensayo? Porque creo en la liberación que brota del Evangelio bien comprendido y de una fe vivida con autenticidad y valor. Porque he descubierto, con tristeza, que se ha convertido a la Negrita en un mito cultural de nuestra Patria, mito que retarda la verdadera dignificación y liberación humanas. Y, finalmente, por amor a la búsqueda de la VERDAD, pues sólo "ella nos hará libres."

\section{María en los evangelios}

La devoción a la Virgen de los Ángeles, es una variación de la devoción a la VIRGEN MARÍA, madre de Jesús de Nazaret. El Nuevo Testamento habla muy poco de María, tanto como figura histórica, corno de ella en tanto símbolo teológico. En los Evangelios de Lucas y Mateo aparece María vinculada a los relatos de la infancia de Jesús. En ellos se describe la relación de María con la misión histórica de Jesús.

Para Mateo, María no es la figura importante, el actor principal es José: él se siente engañado por María y cuando está a punto de abandonarla, en sueños, el ángel le dice que la concepción de su novia se debe al Espíritu Santo. Después, José recibe la visita del ángel que le ordena que huya a Egipto con María y el Niño. Es Mateo quien desde la genealogía de José vincula al Niño con la descendencia davídica. María actúa pasivamente en esta historia.

En el relato de Lucas, por el contrario, María es la figura central. A ella el Ángel le hace la propuesta de convertirse en la madre de Jesús y es ella quien libremente dice sí.

Es interesante notar la libertad personal manifestada por ella en la respuesta que da a la propuesta divina, pues no reacciona como una mujer tradicional, menor de edad, que debe consultar con su padre o con su esposo decisiones trascendentales. 
Es María quien decide visitar a Isabel, su prima y es en esa visita cuando recita su propuesta de justicia y su apego a la línea profética del Antiguo Testamento (el Magníficat). Es María, en el relato de Lucas, la actora principal en el nacimiento de Jesús (Lc. 2, 7). Es la mediadora activa, sin duda, de la misión del Recién Nacido.

Es importante que Lucas diga en el verso 19 del capítulo 2 que: "María, por su su parte, observaba cuidadosamente estos acontecimientos y los guardaba en su corazón". Vale la pena recordar que en la lengua hebrea corazón significa "lo Intimo, lo interior" de la persona en su sentido totalizador, más allá de los sentimientos.

Para los hebreos, el corazón contiene los recuerdos, los pensamientos, los proyectos y las decisiones. Dios les ha dado a las personas un corazón para pensar. También el término corazón, en hebreo, se refiere al centro del ser, ahí donde la persona dialoga con ella misma.

En la antropología bíblica el corazón del ser humano es la fuente de su personalidad consciente, inteligente y libre, la sede de sus elecciones, la ley escrita (Rom. 2:15). Tanto en el Nuevo Testamento como en el Antiguo Testamento el corazón es el punto de encuentro entre Dios y la persona. Esta visión lucana nos hace pensar que María era una mujer plena, mujer totalmente diferente a la descrita por Mateo, capaz de meditar y decidir, desde su corazón, sus acciones y sus visiones de sí misma y de su mundo.

En el verso 34 del mismo capítulo, el anciano Simón canta la grandeza de Jesús y se dirige directamente a María como interlocutora totalmente válida, respetada y admirada por él, situación muy inusual en la cultura patriarcal hebrea.

Cuando a los 12 años el Niño se pierde en el Templo, María y José lo buscan pero es María quien le pide cuentas. Manifiesta así autoridad sobre el hijo y, éste se la reconoce. Y nuevamente en el verso 51 vuelve a decir el evangelista que "María guardaba todas estas cosas en su corazón."

Con ello reafirma su sabiduría y la posesión propia de sí, su señorío. Es, desde la visión que Lucas ofrece de María, desde donde comprendemos su participación activa y vivencial en la redención de la humanidad.

Al aceptar libremente convertirse en la "esclava del Señor", en realidad se está disponiendo, conscientemente, a aceptar una misión de Dios, se está uniendo a la voluntad salvadora de Dios, pidiendo que se haga en ella Su Palabra; El Verbo Creador por el que hizo Dios todas las cosas (Jn. 1:1,5)

Con estas palabras de aceptación libre, María se abandona confiadamente en la perspectiva salvadora de Dios. Y es desde esa actitud de 
humildad cuando surge su entrega confiada, actitud que nace en su fe activa y transformadora.

Desde otra perspectiva podemos afirmar que al llamarse esclava se solidariza con los pobres uniéndose a Dios en Amor. Dios es AMOR y ser esclavo en el amor es ser libre, porque el amor no sojuzga, y quien vive en él y de él queda imposibilitado para sojuzgar a los demás.

En la encíclica MARIALIS CULTUS del Papa Paulo VI (1974), dice:

"Se comprueba con grata sorpresa que María de Nazaret, a pesar de estar absolutamente entregada a la voluntad del Señor, lejos de ser una mujer pasivamente sumisa o de una religiosidad alienante, fue ciertamente una mujer que no dudó en afirmar que Dios es vengador de los humildes y de los oprimidos y derriba de sus tronos a los poderosos del mundo (Le. 1- 51,53); se reconocerá en María, que es "la primera entre los humildes y los pobres del Señor (LG.55), una mujer fuerte que conoció de cerca la pobreza y el sufrimiento, la huida y el destierro (Mat. 2, 1 3-25)."

María así vislumbrada es tan heroica como las mujeres heroicas del Antiguo Testamento que se comprometieron con la justicia de Dios y de la humanidad, como Débora, Judit, Agar, Lía, la Reina Ester, Ana y quién sabe cuántas más cuyos nombres permanecen en el silencio.
Es importante comparar el Canto de Ana (1 Sam. 2, 1 -10) con el de María. Ambos están asentados en el mismo espíritu de liberación y de misericordia hacia los pobres y débiles por los que aboga el Señor y a los que promete hacer justicia:

"Rompe los arcos de los valientes mientras los cobardes se ciñen de valor; los hartos se contratan por el pan, mientras los hambrientos engordan; la mujer estéril da a luz siete hijos, mientras la madre de muchos queda baldia.” (1 Sam 2, 4-5)

"El es santo y su misericordia llega a sus fieles generación tras generación. Su brazo interviene con fuerza, desbarata los planes de los arrogantes, derriba del trono a los poderosos y exalta a los humildes, a los hambrientos los colma de bienes y a los ricos los despide vacíos. ” (Lc 1, 49-53)

Podemos ver cómo ambos cantos tienen como trasfondo el conflicto humano y social generado por la injusticia y por haber contradicho, como humanidad, el plan amoroso de Dios.

Dios decide intervenir por medio de Jesús el Cristo, en el canto de María, para inaugurar unas nuevas relaciones con la humanidad. En el Canto de Ana es el Señor Dios quien hace la justicia:

Pues mira, desde ahora me felicitarán todas las generaciones porque el Poderoso ha hecho tanto por mí:

(Lc.1-48) 
Auxilia a Israel, su siervo, acordándose, de nuestros padres, de la misericordia en favor de Abraham y su descendencia, por siempre. El Señor da la muerte y la vida, hunde en el abismo y levanta; da la pobreza y la riqueza el Señor humilla y enaltece. El levanta del polvo al desvalido, alza de la basura al pobre, para hacer que se siente entre príncipes ..." (1 Sam 2, 6-8)

Ambos son cantos y por ello himnos de alabanza y de alegría y ambas tienen motivos de fe para estar felices en medio de la tragedia que viven con su pueblo:

"Mi corazón se regocija por el Señor, mi poder se exalta por Dios, mi boca se ríe de mis enemigos, porque celebro tu salvación." (1 Sam 2, 1)

"Proclama mi alma la grandeza del Señor, se alegra mi espíritu en Dios mi Salvador." (Lc 1, 47)

Estos cantos se inscriben, además, en la promesa salvífica que Dios ha hecho a su pueblo y de manera especial a los afligidos y afligidas y, a la vez, recuerdan la promesa de restauración de Sión, la cual es signo de la restauración universal del resto afligido y humillado de Israel.

Ana, en su contexto, representaba a Israel y María en el suyo representa a toda la humanidad, por ello puede cantar:

"Desde hoy todas las generaciones me llamarán bienaventurada".

\section{María, mujer de la promesa}

Prometer es una de las palabras clave del lenguaje del amor. Prometer es empeñar nuestra persona y nuestra fidelidad, sentirse seguro de sí mismo y del porvenir. "Dios no es hombre para mentir ni hijo de Adán para retractarse" (Num. 23,19), porque para Dios prometer es ya dar, cumplir. Prometer es, también, y de manera importante, tener fe capaz de esperar en la esperanza y en la desesperanza.

Es también, hacer brotar, en quien recibe el don, el agradecimiento sincero que se expresa en la acción de gracias que reconoce, en el cumplimiento de la promesa, el corazón del Dador. Para la historia de salvación del pueblo de Israel, las promesas son su clave:

Así se han realizado sus promesas hechas en el pasado, por la boca de sus santos profetas, de salvarnos de nuestros enemigos y del poder de aquellos que nos odian. Así demuestra (Dios) ahora la bondad que tuvo con nuestros padres y así se acuerda de su Santa Alianza, pues a nuestro padre Abraham le juró bajo palabra, que Él nos libraría de las manos de nuestros enemigos." (Lc. 1, 70-73).

El judaísmo manifiesta, por una parte, la confianza en las promesas $\mathrm{y}$, por otra, su carácter de recompensa, mediante la obediencia a los mandamientos; es necesario merecer la herencia prometida. El cristianismo, en cambio, reconoce en 
las promesas la exclusiva iniciativa de Dios, el regalo prometido a todos y todas las creyentes. Pablo insiste en que la base de la vida cristiana es la fe y se siente obligado a precisar que la esencia de las Escrituras es la promesa dirigida a Abraham que se hace realidad en Jesucristo:

"Ahora bien, lo que Dios prometió a Abraham era para su descendencia. La Escritura no dice: para los descendientes como si hubiera varios, sino que habla en singular. Ella dice serán para su descendencia y ésta es Cristo. Ahora digo lo siguiente. El testamento que Dios hizo en debida forma, no lo puede anular la Ley, que vino 430 años después, ni pudo dejar sin efecto la promesa de Dios. Pero, si tenemos que observar una Ley para conseguir la herencia, ésta ya no tiene carácter de cosa prometida, sin embargo, Abraham recibió esta promesa como regalo de Dios" (Gal. 3, 16-18).

Esta visión de gratuidad de la promesa de Dios debe llevar al creyente a comprender con el corazón, como María. Dios, al cumplir con la humanidad su promesa, invita a un cambio de sensibilidad, ya que es imposible permanecer en una relación de negocio con Dios.

Todo lo que Él da y ofrece es gratuito, y sólo nos pide que tengamos fe en Él y en sus promesas. María al igual que Jesús, su hijo, colocan en el centro de esta nueva sensibilidad al corazón, criticando así, desde sus raíces, a la cultura androcéntrica patriarcal, la que, generalmente, se burla de los sentimientos y los considera de mucha menor valía que el pensamiento y el razonamiento.

Jesús, por el contrario, nos indica que lo fundamental de una nueva sensibilidad radica en un cambio de corazón, como ya lo anunciaban los profetas:

"Les daré un corazón nuevo y un nuevo espiritu, quitándoles el corazón de piedra y poniéndoles un corazón de carne. (Ez. 11, 19)

El profeta Isaías en el capítulo 49, en los versos del 13 al 15, manifiesta esta nueva sensibilidad, a la vez que, metafóricamente, nos muestra el cumplimiento de la promesa, por parte de Dios:

¡Cielos griten de alegría! Tierra, alégrate. Cerros, salten y canten de gozo porque Yahvé ha consolado a su pueblo se ha compadecido de los afligidos.

Y Sión decia: "Yahvé me ha abandonado," el Señor se ha olvidado de mi". Pero, ¿puede una mujer olvidarse del niño que cría, o dejar de querer al hijo de sus entrañas? Pues bien, aunque alguna lo olvidase, ;Yo nunca me olvidaré de ti!

En Mateo 15,8-9, Jesús con fuerza recalca su invitación para vivir una nueva sensibilidad: "Este pueblo me honra con la boca, pero su corazón está lejos de mí. El culto que me rinde 
no sirve de nada, y sus enseñanzas no son más que mandatos de hombres." Una vez más remite al amor en su forma más completa, como misericordia, como compasión, como ternura, lo que manifiesta, metafóricamente, comparándose con una gallina con pollitos, en Mateo 23, 37.

Es por el camino de la misericordia por el que Jesús nos invita a adquirir una nueva forma de sentir y de relacionarnos; es un sentir desde las entrañas, como sienten las mujeres, y de manera especial María la mujer madre de Jesús. Sólo cuando se comprende que quien hace y cumple promesas es Dios y que a cambio de sus regalos de vida no espera ni exige recompensa ni sacrificio. Es cuando se descubre el sentido, absolutamente generoso y gratuito del amor de Dios a la humanidad.

María, como los demás pobres de Yahvé, perteneció al resto fiel a la promesa de Dios. Su vida estuvo envuelta en la misma clase de situaciones sociales opresoras, y difíciles que padecían los pobres de su tiempo y que aún sufre y padece la gente marginada de los pueblos tercermundistas. María sufrió la fuerte discriminación de las mujeres de su tiempo, incluso en el aspecto religioso.

Ella fue consciente de su pequeñez e insignificancia para su sociedad y su cultura, aceptó su posición humilde, según el espíritu de fidelidad a la promesa, de los pobres de Yahvé. Su seguridad está en Dios, el misericordioso que mira a los de abajo para socorrerlos y ayudarlos. Desde esta adhesión absoluta a Dios, María se compromete en la búsqueda y realización de la verdad, la justicia y el amor. Ella, como cualquier madre terrena, educa a su hijo según sus convicciones y principios; por ello es hermoso pensar que María estaba en relación armoniosa con el plan de salvación de Dios y que desde esa sintonía de amor formó a su pequeño. Pero, para ser justos, se debe reconocer que José, el padre de Jesús, pertenece también a los pobres de Yahvé, y por lo tanto es fiel a su promesa desde su misión paternal.

El sí de María la compromete con el servicio a la vida y a la justicia. Ejemplo de ello es su Magnificat (poner abajo lo que está arriba y viceversa). María, desde su fe y a causa de ella, intuye el valor absoluto del Reino de Dios y halla "el tesoro escondido" y "la perla de gran valor"'(Mat 1 3,44-4 5). Este hallazgo la lleva a permitir que en su cuerpo, y por él, Dios "pueda infiltrarse en el tejido de la vida y de la historia humana para que una humanidad herida e impotente pueda alcanzar un destino que está irremediablemente fuera de su alcance, que es el Reino de Dios" (Segundo Galilea, El Reino de Dios y la liberación del hombre).

\section{María la llena de gracia}

La humanidad está en permanente búsqueda de identidad y de 
perfección. Soñamos con mundos mejores y felices, coronados por la paz y la justicia. Ansiamos la armonía y tenemos esperanza en un futuro mejor. Queremos sanar todas las penas y calamidades esperando derrotar, algún día, a la muerte y al dolor. Acompañados por estos sentires y pensares, caminamos con esperanza por el sendero cotidiano del conflicto y la ambigüedad.

María también vivió de esta manera. Sin embargo ella, que es madre de la Esperanza, vivió el "claro oscuro de la fe" con mayor confianza que los y las demás, gracias a su gran capacidad de amar y de esperar pues, ella ha sido proclamada por Dios como la llena de gracia y, estar llena de gracia significa "tener la presencia de Dios, significa armonía total con Dios en el pensar, sentir y actuar." (L. Boff, El Rostro materno de Dios).

Mas no se crea que pasivamente la gracia va a dar sus frutos. María es ejemplo de actitud responsable, de entrega confiada y de disponibilidad activa, así manifiesta vivencialmente su sí de aceptación.

La presencia de Dios en María alcanza una nueva significación y un especial relieve, al serle encomendada una misión única: ser la madre del Salvador, "verdadera casa de Dios y puerta de entrada para Dios en nuestra historia" (Vidal Ayala, Con María en oración).

Así queda vinculada, profundamente, a la misión salvadora de
Jesús. La fuerza de Dios presente en ella le da valor y entereza para vivir y dar testimonio de su fe. Lo mismo sucede a quienes se entregan, confiadamente, a la Gracia del Señor.

Para enriquecer estos conceptos se transcribe a continuación una cita de Leonardo Boff, de su libro El Rostro Materno de Dios: "Confesar que María es llena de gracia, significa admitir que Dios como bondad, suavidad, alegría, rectitud, equilibrio, transparencia, libertad, y exuberancia en todas las dimensiones de la vida, se dio a sí mismo a esta sencilla mujer del pueblo."

La gracia no constituye "una cosa misteriosa" en el hombre, sino que es la presencia personal y viva del propio Dios, dentro de la vida, para hacerla más vida todavía, plenamente abierta a la tierra y al cielo. El nuevo estilo de vida instaurado por Jesucristo dice que ahora estamos regidos por la gracia, no por la ley. "Dios nos había dado la ley, por medio de Moisés, pero por Cristo Jesús, llegó el amor y la fidelidad." (Jn. 1,17)

"El pecado ya no los volverá a dominar pues, ustedes no están ya bajo la Ley, sino bajo la gracia." (Rom. 6,14). La gracia es el don que brota de la generosidad del Dador $\mathrm{y}$ envuelve en esta generosidad a quien lo recibe. La gracia, revelada y dada por Dios en Jesucristo está presente, como hemos dicho, en el Antiguo Testamento como promesa y 
esperanza. El salmo 36,8 ss, nos dice a este respecto:

"jcuán preciosa es tu gracia, oh Dios! Los hombres se refugian a la sombra de tus alas, se sacian de la sobreabundancia de tu casa y los abrevas en el torrente."

En el salmo 64, verso 4:

"Porque tu gracia es mejor que la vida".

Pareciera que ante la gracia de Dios, la vida palidece. Sinónimos de gracia son expresiones como: generosidad de Dios, misericordia que se interesa por la miseria, fidelidad generosa, justicia inagotable, pero la palabra que sin duda traduce mejor el efecto producido en el ser humano por la gracia (generosidad de Dios), es bendición.

Bendición es mucho más que protección. En quien la recibe mantiene la vida, el gozo, la plenitud de la fuerza. Establece entre Dios y su criatura una relación personal, "hace que se pose sobre el hombre, la mirada y la sonrisa de Dios y la irradiación de su rostro y de su gracia y esta relación tiene algo vital, afecta la potencia creadora." (Jacques Guillet, Vocabulario de teología bíblica de León Dufor).

La gracia es fecunda y gratuita; es, además, el secreto de la redención. Así la salvación es don de Dios y no salario merecido por un trabajo, pues de lo contrario la gracia ya no sería gracia.

"Ahora bien, cuando alguien hace una obra no se le entrega su salario como un favor, sino como deuda. Por el contrario, quien no tiene obras que mostrar, pero cree en el que hace santos a los pecadores, a ese tal se le toma en cuenta su fe y, como un favor, se le hace santo". (Rom. 4, 4-5).

"Solamente la fe en la promesa respeta el verdadero carácter de la obra de Dios, que consiste en ser ante todo una gracia" (Jacques Guillet, Vocabulario de teología bíblica de León Dufor).

Y la gracia de Dios "no es estéril" (1 Cor. 15,10). Abre sin reservas la riqueza de Dios y la prodiga sin medida. Por la gracia, la fe produce obras y realiza actividades dadoras de frutos de amor y salvación:

"pues por la bondad de Dios han recibido ustedes la salvación por medio de la fe. No es esto algo que ustedes mismos hayan conseguido, sino que es un regalo de Dios. No es el resultado de las propias acciones, de modo que nadie puede gloriarse de nada; pues es Dios quien nos ha hecho; el nos ha creado en Cristo Jesús para que hagamos buenas obras, siguiendo el camino que Él nos habia preparado de antemano." (Ef. 2. 8-10) 
De lo dicho se concluye que Dios no quiere establecer contratos calculados, ni respuestas a medias, sino entrega total, como la de María. Ella se compromete con la práctica de Jesús de dar vida, de transformar la tierra vieja en nueva y al ser humano viejo en uno nuevo. A esto la llevan la fe en Dios, promesa y gracia. En María la característica principal de su unión con Jesús es una fe profunda que se hace razón de su existir y que le da sentido a su quehacer humano.

Para las y los cristianos, desde el ejemplo de María, la experiencia de Dios debe ser asumida como esfuerzo hacia la transformación personal y del entorno; así transitarán por "el camino preparado por Dios, de antemano".

A esta altura del estudio, también podemos concluir que la fe, en el cristianismo, no se reduce a la aceptación de un compendio de verdades, sino que, por el contrario, la fe impulsa a la tarea de construir la historia personal y comunitaria según los criterios de Jesús, que son los mismos del Padre y los vividos por María. Por ello la fe se traduce en obras de transformación por la justicia y el amor.

De ahí que las y los seguidores de Jesús y de María de Nazaret tengan como meta principal, en el mundo, dar frutos de vida y ser testigos proclamadores de la luz: "Dios es la luz, en El no hay tiniebla alguna. Si decimos que estamos en comunión con Él, y caminamos en tinieblas, mentimos." ( Jn. 1,5-6)

\section{María, mujer de fe}

Jesús pedía una única cosa a quien se le acercaba en demanda de un milagro: tener fe. Para entrar en su Reino, para seguirlo, la condición indispensable es creer en su palabra y confiar en Él. María es la primera mujer del Nuevo Testamento en creer en la palabra de Jesús y en poner toda su confianza en Él; por ello es la primera creyente cristiana.

María es un ejemplo de fe madura, alcanzada, conquistada desde experiencias nuevas, desde cambios inesperados y desde una lenta comprensión del Misterio de Dios.

Afirma el Concilio Vaticano II (LG. n. 58) que "María avanzó en la peregrinación de la fe", con lo cual se pone de relieve cómo María vive una fe progresiva como realidad fundamental, aceptando lo inesperado y confiando plenamente en Dios. Toda experiencia de fe es donación de Dios y requiere esfuerzo del ser humano, y exige unas actitudes fundamentales. La fe exige, como actitudes fundamentales, amor y confianza; María vivió ambas plenamente. Ella comprendió desde sus entrañas que la fe es vida en Dios.

El teólogo latinoamericano, Leonardo Boff, ofrece una definición de fe que se puede afirmar que es la vivida por María: 
"Fe es aquella manera de vivir y de pensar por la cual se relacionan con Dios todas las cosas de este mundo y de la experiencia humana. Todo se ve, se interpreta y se vive a la luz suprema de Dios."

La fe de María, como la de todos los creyentes, sin duda, presentó, además de certezas, dudas, las que fueron aclarándosele durante la evolución y crecimiento de su experiencia de vida con Dios y con Jesús. Como dice Michel Quoist en A corazón abierto: "con frecuencia la fe no es más que una larga cadena de dudas vencidas por el amor." A vencerlas nos invita la fe.

“iDichosa tú que has creido!” (Lc. 1, 45). Estudiando la historia de María queda claro que recorrió los caminos de Dios para descubrir su sentido y para acoger los designios de Dios con disponibilidad plena: "Yo soy la esclava del Señor; que Dios haga conmigo como me has dicho." (Lc. 1, 38)

La fe solicitada por Jesús a sus seguidores es, como afirma J.M. González Ruiz, "una marcha dentro de la historia." (Creer es comprometerse) Esta marcha, para que sea auténticamente cristiana ha de ser profética, tanto en la denuncia como en el anuncio. La verdadera fe cristiana, por lo tanto, es una praxis comprometida. En la Constitución Conciliar de La Iglesia en el Mundo
Actual, del Concilio Vaticano II, se afirma a este respecto:

"Se equivocan los cristianos que, pretextando que no tenemos ciudad permanente, pues buscamos la futura, consideran que descuidar las tareas temporales, sin darse cuenta de que la propia es un motivo que los obliga a un más perfecto cumplimiento de todas ellas, según la vocación personal de cada uno." (Constitución Conciliar de la Iglesia en el mundo actual. n.43).

Por otra parte cuentan los Hechos de los Apóstoles que después de que Jesús fue elevado al cielo, los apóstoles, junto con otras mujeres se reunieron en el piso alto de la casa en que estaban alojados: "Todos ellos se reunian siempre para orar con algunas mujeres, con María, la madre de Jesús y con sus hermanos" (Hech. 1,14)

La cita anterior nos hace vislumbrar la entrega de María a su tarea de acompañar e inspirar a los apóstoles y discípulos y discípulas de Jesús; no se queda mirando para el cielo buscando la "ciudad futura".

Durante toda su vida, al igual que las mujeres de su tiempo, trabajó lo mejor que pudo para servir a su familia, y para colaborar en las actividades de su pueblo. Igual que su hijo Jesús y que su esposo José, vivió inmersa en el mundo, en la historia y es en ella y desde ella desde donde se compromete con Dios en la salvación 
de la humanidad. Su fe, antes de desligarla del mundo, la involucra más en las tareas cotidianas desde las que cumple su compromiso con Dios y con la humanidad.

Movido por la fe, Pablo, en la segunda carta a los Tesalonicenses les llama la atención a los ociosos a la vez que los insta a todos y a todas a hacer el bien: "Es que nos hemos enterado de que algunos de ustedes viven en la ociosidad, muy ocupados en no hacer nada; a éstos les mandamos y recomendamos en nombre de Jesucristo, el Señor, que trabajen pacificamente $y$ asi ganen para comer. Por su parte ustedes hermanos, no se cansen de hacer el bien." (2 Tes 3,11)

Sean suficientes estas palabras para recalcar que la fe de María, además de ser comprometida, es una fe activa, transformadora, develadora del misterio, como la quiere Dios.

\section{María, mediadora}

"Santa María, madre de Dios, ruega, Señora, por nosotros pecadores, ahora y en la hora de nuestra muerte."

"Dios te salve Reina y Madre, madre de misericordia, vida y dulzura, esperanza nuestra. Dios te salve, a ti llamamos los desterrados hijos de Eva. A ti suspiramos, gimiendo y llorando en este valle de lágrimas. $E a$, pues Señora, abogada nuestra vuelve a nosotros, esos tus ojos misericordiosos y después de este destierro muéstranos a Jesús, fruto bendito de tu vientre, joh clemente, oh piadosa, oh dulce Virgen María! Ruega por nosotros, santa Madre de Dios, para que seamos dignos de alcanzar las promesas de nuestro Señor Jesucristo."

Este ejemplo milenario de oración a María, revela que el pueblo de Dios, de manera intuitiva, le ha dado el carácter de mediadora de todas las gracias. Sin embargo, la teología afirma que el único mediador es Jesús, ¿cómo, entonces, armonizar la visión teológica oficial con esta vívida y profunda intuición y experiencia de fe del pueblo?

En Hebreos 9, 15 y 12,24 se afirma que Jesús es el único mediador de la nueva alianza, entre Dios y la humanidad:

"Por eso, Jesucristo es mediador de una nueva alianza y un nuevo testamento, pues con su muerte libra a los hombres de sus pecados cometidos bajo la primera alianza, y hace posible que los que Dios ha llamado reciban la herencia eterna que él les ha prometido," "... a Jesús mediador de una alianza y a la sangre con que hemos sido purificados, la cual nos habla mejor que la sangre de Abel".

Declarar que Jesús es el único mediador podría significar que los seres humanos ya no tienen papel alguno en la historia de la salvación; sin embargo, la mediación de Jesús, 
aquí en la tierra, reviste símbolos sensibles. Jesús confía a sus seguidores y seguidoras una función para con la iglesia.

Jesús llama a sus apóstoles, discípulos y discípulas a trabajar con Él, para proclamar la Nueva Buena Noticia de su Reino, para manifestar los signos que lo presentan, es decir que lo hacen visible a nuestros ojos:

"Jesús envió a estos doce con las siguientes instrucciones: no vayan a las regiones de los paganos ni entren en los pueblos de Samaria, vayan más bien a las ovejas perdidas del reino de Israel. Vayan y anuncien que el reino de los cielos se ha acercado" (Mat. 10, 5-7).

Los enviados realizan actos por los que se manifiesta la mediación de Jesús, y este envío sigue siendo mediación en los seguidores y seguidoras de Cristo Jesús, hoy. En Mateo 28, 19 -20, se manifiesta la misión de Jesús a sus seguidores (as) para después de su muerte y resurrección:

“Jesús se acercó a ellos y les dijo: -Dios me ha dado toda autoridad en el cielo y en la tierra. Vayan pues, a las gentes de todas la naciones, y háganlas mis discípulas; bauticenlas en el nombre del Padre, del Hijo $y$ del Espíritu Santo, y enséñenles a obedecer todo lo que les he mandado a ustedes. Por mi parte, yo estaré con ustedes todos los días, hasta el fin del mundo."
Desde nuestra práctica de fe, realizar esta misión es mediar entre Dios y la humanidad de manera creativa, participativa y transformadora. Al comprometernos con la misión salvadora de Jesús, desde nuestra vida cotidiana, nos hayamos unidos a su acción liberadora, somos uno o una": Por Él y con su Padre en el Amor del Espíritu Santo.

Si Jesús nos llama a esta unidad fraterna, ¿cómo vamos a estar excluidos (as) de ejercer mediación unos por otros (as)? Mediar es sinónimo de amar activamente, de unirse a la Gracia Plena para hacer presente la redención de Cristo en la comunidad fraterna. A partir de Pentecostés Jesús comunica a su iglesia el Espíritu que ha recibido del Padre; así pues "ya no hay más que un cuerpo y un espiritu, como no hay más que un solo Señor y un solo Dios." (Ef. 4, 4)

Vale la pena preguntar, también, ¿qué sentido tienen los carismas otorgados por el Espíritu si estamos excluidos (as) de la tarea de mediación? Particularmente, creo que no es totalmente correcto hablar de Cristo como mediador único en el sentido de exclusivo, pues estaríamos negando la libertad, la acción creadora y los carismas con que hemos sido creados y creadas. Por respeto a esa libertad otorgada por Dios, desde su génesis a la humanidad, Jesús comparte con todos y todas. Su acción es mediadora, de lo contrario dejaríamos de ser los seres creativos y participativos; 
mediante la acción personal y comunitaria, libre y consciente, crecemos y nos realizamos como hijos e hijas de Dios.

Sería contradictorio aceptar, según dicen muchos y muchas en la Iglesia que sólo somos instrumentos en las manos de Dios y, como tales, instrumentos de la mediación de Jesucristo.

Por otra parte, somos el pueblo de Jesús que participa junto a Él de su realeza. María está asociada como todos los elegidos (as) a la intercesión de Jesús, y con un valor especial que le da el ser su madre y la de todos sus discípulos y discípulas: "Pero a quienes lo recibieron y creyeron les concedió el privilegio de llegar a ser hijos de Dios. Y son hijos de Dios, no por la naturaleza ni los deseos humanos, sino porque Dios los ha engendrado". (Jn. 1, 12-13). ¿Cuánto más María que fue la primera en recibir y aceptar amorosamente a Jesús?

Dios, en el Antiguo Testamento suscitó múltiples mediadores entre Él y su pueblo y preparó y anunció la mediación que su pueblo ejercía entre Él y toda la humanidad. Esta mediación de Israel se realiza en la mediación de Cristo, único mediador, único en la grandeza insondable que le viene del hecho de ser el Hijo.

"No obstante, siendo cabeza del Nuevo Israel no ejerce su mediación sino por el cuerpo que El ha suscitado" (André Alphonse Viard, O.P., Le saulchoir Essone) Esta interpretación nos permite ampliar la concepción de mediación, porque recuerda que Dios es Amor, y que por lo tanto en Él no caben las exclusiones que impiden la mutua realización de los seres humanos.

Unida a la concepción de mediación está la de solidaridad. La vida terrena de María nos muestra su solidaridad con los y las demás. Recordemos su petición de ayuda a Jesús para los novios de las bodas de Caná (Jn. 2, 1-11) y la visita a Isabel su prima anciana, embarazada a quien va a ayudar y a acompañar, así como a compartir su alegría maternal con ella (Lc. 1, 39-45). Otra muestra tangible de su solidaridad la constituye el acompañamiento, a su hijo, en el camino de la cruz, así como su permanencia al pie de ésta (Jn. 19, 25-27).

Pero su mayor muestra de solidaridad la constituye su sí para convertirse en madre de Jesús, hecho que la une al destino de la humanidad y a la misión salvadora de Dios en Jesús. Esta concepción de solidaridad es inclusiva, porque como asegura L. Boff en Encarnación: la humanidad y la jovialidad de nuestro Dios: "se refuerza y maximaliza una estructura que envuelve a todos los seres humanos." Al respecto también dice Boff en el mismo texto: "La reducción a la mediación única y exclusivamente a Jesucristo recorta la comprensión del misterio de Dios y del ser humano." 
Para enriquecer lo ya dicho sobre mediación y solidaridad reproducimos los siguientes pensamientos de L. Boff, en la obra señalada: "Ningún ser humano se presenta, en concreto, como un átomo desarraigado. Su ser echa raíces en la infraestructura material y corporal, se extiende hacia adentro de la contextura social, asume dentro de sí toda la carga histórica del pasado. No se presenta como natural, sino como cultural, esto es, como ya hecho y construido y en cierta forma todavía por hacer.

Decimos que el hombre no es nunca un individuo, sino una persona. Por persona expresamos el carácter específico del ser humano en cuanto que se presenta como capacidad para la comunión ilimitada y para la producción de símbolos por los cuales confiere un significado al mundo y a su acción sobre él." (Ibid, L. Boff)

Con esta concepción de fondo podemos hallar que en el Evangelio de Jesús se manifiestan las necesidades y características humanas de las personas históricas, de ahí que sea un mensaje de vida y esperanza para todos y todas. En él tienen eco y resonancia las aspiraciones más nobles de la humanidad.

Los derechos humanos están presentes: la fraternidad, la igualdad, la libertad, la justicia, la paz, el amor como síntesis, siempre actual, de vida, ¿no es ello signo de la solidaridad divina para con la humanidad e invitación que compromete a las personas a ser solidarias y en tanto lo sean a mediar las unas por las otras? $y$, ¿acaso no es esta solidaridad entre unos y otros signo del amor a los semejantes y a Dios?...

Entonces, ¿cómo negar a los seres humanos y a María su capacidad de mediadores (as) si el serlo es manifestación concreta de amor al que somos invitados? Además, la palabra de Dios, su Evangelio, está siempre viva y mantiene su actualidad a través del tiempo, porque responde a las necesidades más acuciantes del ser humano. Es fuente de sabiduría y camino de realización en lo humano y en lo cristiano y ofrece posibilidades para el crecimiento solidario.

Así la historia de la salvación, narrada en el Antiguo Testamento, va preparando el hecho central de la solidaridad de Dios con nosotras y nosotros: hacer presente a Dios en la historia, por medio de Jesús, y comunicar su mensaje de liberación al realizar su entrega en el supremo gesto de Amor de la Encarnación, gesto que es posible gracias al amor solidario de entrega de María, quien así se convierte, por derecho propio, en la mediadora entre Dios y la humanidad y viceversa.

De esta manera queda demostrado que mediación y solidaridad son manifestaciones concretas del amor divino y humano y que, por lo tanto, si queremos vivir unidos por el AMOR, hemos de mediar 
solidariamente entre nosotras y nosotros y Dios. Mediación, por tanto, es manifestación concreta del amor.

En el número 37, de Lumen Gentium, leemos: "De este ejemplo se deduce claramente que la figura de la Virgen Santísima no desilusiona ciertas aspiraciones profundas de los hombres de nuestro tiempo, sino que hasta les ofrece el modelo acabado del discípulo del Señor: el obrero de la ciudad terrena y temporal y al mismo tiempo peregrino diligente en dirección hacia la ciudad celestial y eterna; promotor de la justicia que libera al oprimido y de la caridad que ayuda al necesitado, pero sobre todo testigo activo del amor que edifica a Cristo en los corazones". (Lumen Gentium n. 37)

¿Cómo podemos tratar de ser todo lo que fue ella, sin mediar y solidarizarnos? Pareciera que algunos grupos cristianos, en su afán de divinizar tanto a Jesús, minusvaloran al resto de los seres humanos hasta convertirlos en instrumentos en manos de Dios. También es válido preguntarse si quienes le niegan la mediación a María tienen en su inconsciente el prejuicio de que es mujer. Sea como sea, afirmamos que es el amor quien edifica a Cristo en los corazones, y que para que esta edificación se dé debe haber un sujeto activo del amor.

Para complementar lo dicho le tomaremos prestado un trozo de pensamiento a L. Boff:
"No existen islas solidarias. Todas están ligadas por las aguas. Todos participan del destino de todos.

No sólo respiramos el mismo aire, habitamos la misma tierra, estamos cubiertos por el mismo cielo, sino que principalmente participamos de la misma naturaleza humana. (...) y nos vemos afectados por sus expresiones culturales, al mismo tiempo que influimos también en ellas cada uno de nosotros. Esta solidaridad no es voluntarista; no surge porque así lo querernos nosotros; existe independientemente de nuestras decisiones. (...)

En este transfondo es donde debe situarse la temática de la mediación. Por mediación entendemos los vínculos que aproximan y unen a las personas. (...) Los hombres viven en las mediaciones, porque todo lo que hace cada persona, lo que deja de hacer, se realiza en comunión y solidaridad con todos." (Boff, Leonardo, $E l$ rostro materno de Dios)

Como hemos visto, María desempeñó un papel fundamental en la historia de la salvación y su acción no finalizó cuando fue llevada a la gloria. Allí continúa mediando, solidarizándose con sus semejantes, con sus hijos e hijas. En el Credo confesamos la comunión de los santos, lo cual significa "reconocer que todo el bien que se practica en el mundo, toda elevación que se lleva a cabo en los espíritus, todo crecimiento en dirección a los demás o bien hacia Dios, permanece encerrado dentro de 
los límites de la persona, pero circula por todos y alcanza al mismo cielo." (L. Boff, Ibid)

Todos los seres humanos estamos enlazados por la mediación; ella es consustancial a la vida misma, pues vivimos, a veces, a pesar nuestro, en comunión.

Por otro lado, la figura de María no queda suficientemente aclarada únicamente desde su relación con Dios, sino que hay que pensarla, también, referida a los seres humanos. Es la manera de llegar a comprender su misión como vocación de entrega libre. Podemos decir que a ella le preocupan los seres humanos en la perspectiva del plan salvador de Dios y en la perspectiva amorosa de Jesús.

"Goza en la adhesión de los discípulos y gentes sencillas; se siente turbada por la oposición de las autoridades religiosas; observa cómo el conflicto se hace inevitable, hasta desembocar en la inmolación de Jesús. Está presente en el nacimiento de la iglesia primitiva. Se integra a ella como una creyente más, pero con una significación profunda." (V. Ayala, Con María en oración)

Es claro, después de todo lo dicho, que la tarea de María al lado de Jesús fue el principio de su actuación y preocupación por la humanidad.

$\mathrm{Su}$ vida muestra el sentido de donación completa, el mismo sentido de donación de Jesús. Hoy continúa cuidando de los hermanos y las hermanas de Jesús, especialmente de aquellos y de aquellas que viven entre dificultades y peligros que podrían alejarlos del camino de su Hijo.

$\mathrm{Su}$ preocupación permanente, estamos seguras, es ayudarnos a comprender a Jesús y su mensaje, así como a encontrar el camino de realización y felicidad al que nos invita nuestro Creador. La imaginación teológica del pueblo de Dios le da a María varios y variados títulos como intercesora: abogada, auxiliadora, socorro, mediadora, títulos que el Concilio Vaticano II reconoce como válidos (LG. 62).

Es también preciso destacar el significado teológico de los iconos marianos orientales. Siempre presentan a María con Jesús, la que nos trae a Dios, sostiene con amor al Niño, mientras la mirada de María se dirige hacia nosotros. Ejemplo especial, en nuestro país, es el icono oriental de la Virgen del Perpetuo Socorro.

También el pueblo ha creado letanías que señalan a la Virgen como intercesora tierna: Refugio de los cristianos, Consoladora de los Afligidos, Arca de la Alianza, Puerta del Cielo, etc. A continuación ofrecemos una plegaria poética de autor desconocido que ofrece, desde la imaginación teológica, un retrato poético de la imagen de María de nuestro pueblo creyente: 
"María, virgen del amor apacible, corazón abierto, Madre de la mano tendida a cada instante; eres faro de luz brindada, a tiempo pleno, a la densa noche de nuestros caminos sin norte.

Eres vigía, timonel en vela, ruta cierta, para apartar la fosa de nuestros laberintos. Eres impulso certero, nuestro brazo fuerte, para afrontar escollos, oscuras borrascas, rompientes.

Tu amor, María, presto y diligente, monta guardia permanente a nuestro lado, enciende luces de vigilia hasta el alba y abre puertas, balcones, claraboyas en el ancho día; averigua, atenta, la necesidad y la ocasión del miedo, previene la herida sorda al alma, y acude prontamente, ternura en bandolera, al lugar preciso en que el dolor estalla y quema.

Tu amor convoca, a la continua tarea de darte, al corazón, al tiempo, a la mano y la mirada. Toda tú te agolpas, María, para ser siempre socorro, ayuda eficaz a nuestra condición de humanas impotencias.

Te sentimos cercana, generosa, amor en ascua, y a ti nos acogemos, Madre de la mano tendida y del mirar siempre puro hacia nosotros."

(Plegaria poética de autor desconocido. Escrita en el libro Con María en oración, de Ayala Vidal)

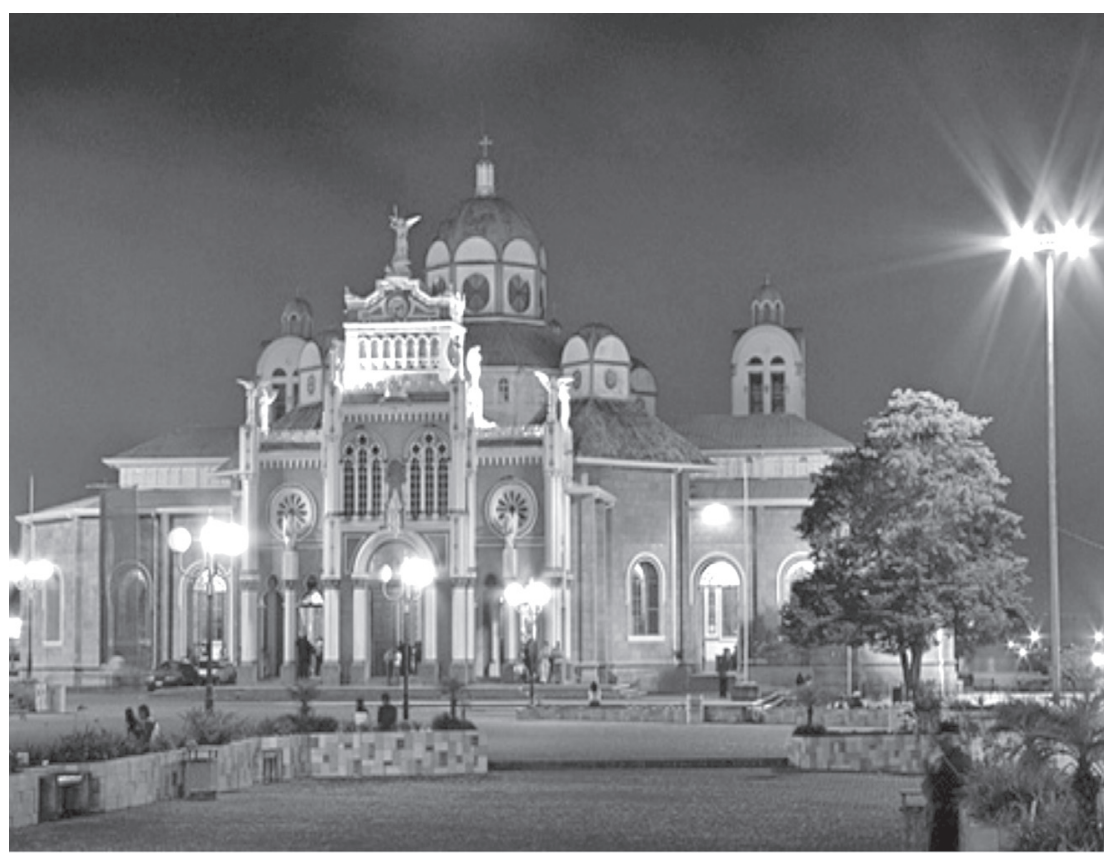

Foto por: Roberto García. 


\section{María, mujer de los milagros}

Muchas personas hoy consideran caduca la noción de milagro, inversamente; hoy también muchos grupos se muestran ávidos de falsas maravillas (maravillosismo) que se tienen como milagro. En los últimos tiempos se habla de apariciones de la Virgen y de múltiples milagros realizados por ella, según creen las mayorías marianas; por ello es sumamente importante, para cumplir con los objetivos de este trabajo, aclarar, teológicamente, la visión cristiana de milagro.

La Biblia reconoce en todas partes la mano de Dios, que manifiesta a la humanidad su amor salvador. El universo creado es maravilla y signo de vida, así como las intervenciones de Dios en la historia, y éstas a la vez son "creación renovada", aun cuando el historiador común las considere como ordinarias y explicables.

Por otra parte, la Biblia ignora las distinciones modernas entre acciones providenciales, y las causas naturales excepcionalmente convergentes, acción divina que sustituye el funcionamiento de los agentes naturales o causas segundas, por lo que concentra la mirada del creyente en el elemento esencial, común a todas las categorías: la significación religiosa de los hechos.

Así, por ejemplo, San Agustín, con los ojos de la fe, reconoce tanto en el crecimiento de la mies, como en la multiplicación de los panes, el sello del amor y del poder divinos, y los distingue, únicamente, en razón de la costumbre o del asombro de sus beneficiarios.

Desde esta óptica la manifestación milagrosa no tiene la importancia que suele dársele; lo único que importa es la lección que oculta el gesto simbólico: mostrar la presencia protectora y salvadora de Dios. El Antiguo Testamento muestra en los milagros revelaciones de Dios y signos eficaces de salvación.

Por otra parte, la subordinación del milagro a la palabra de Dios sirve para distinguir los verdaderos milagros de los maravillosos, operados por los magos y los falsos profetas. Moisés y Aarón fueron a ver al faraón e hicieron lo que el Señor había ordenado; Aarón lanzó su bastón al suelo delante del Faraón y sus funcionarios, y el bastón se convirtió en una serpiente.

El Faraón, por su parte, mandó llamar a sus sabios y magos, los cuales con sus artes mágicas hicieron también lo mismo: Cada uno arrojó su bastón al suelo y cada bastón se convirtió en una serpiente, pero el bastón de Aarón se comió los bastones de los sabios y magos. (Ex. 7, 10-12)

A la palabra aportan su apoyo los signos milagrosos, y no al revés, pues revelan con gestos concretos la salvación proclamada por los heraldos de Dios, a los que acreditan como sus mensajeros auténticos. 
Para completar lo dicho citamos las palabras del teólogo Paul Ternant:

Los milagros se distinguen entre todos los signos por su eficacia y su carácter extraordinario. Por una parte, realizan habitualmente lo que significan (...) Por otra parte, estas obras, a pesar de lo que puedan tener de hechos naturales (lluvia, sequía), rebasan las más de las veces lo que el hombre está acostumbrado a ver en el universo y lo que él mismo puede realizar. Asi el milagro es un signo particularmente revelador del poder de Dios (...) Asi pues, en definitiva los milagros son signos eficaces y dones gratuitos del amor de Yahvé. Sólo Jesús revelará plenamente la universalidad de este amor salvador". (Campos, Luis y otros. Pastoral y lenguaje, CELAM)

Los milagros tienden a provocar y a confirmar la fe. Como decía Pascal, los milagros disciernen la doctrina y la doctrina discierne los milagros. En cuanto a los milagros realizados por Jesús es menester decir que: "movido por su misericordia, hace retroceder, eficazmente a la enfermedad, a la muerte, a la hostilidad de la naturaleza, en una palabra a todo el desorden introducido en la vida por el pecado" (Paul Ternant, Ibid).

Además todos sus milagros reflejan eficacia salvífica y señalan hacia su Mensaje. Es importante también pensar en el mensaje que transmite Jesús en Mateo 1 7, 20: "Jesús les dijo:-Porque ustedes tienen muy poca fe. Les aseguro que si tuvieran fe, aunque sólo fuera del tamaño de una semilla de mostaza, le dirían a este cerro: "quítate de aquí y vete a otro lugar", y el cerro se quitaría".

"Nada les sería imposible." La expresión literaria "quitar cerros" significaba en tiempos de Jesús hacer algo extremadamente difícil, e incluso imposible. Con ello Jesús testifica el poder de la fe, condición esencial de la salvación y del seguimiento de Jesús.

Es preciso recalcar, aquí, el marcado sentido histórico del mensaje bíblico. En la Biblia se narra la historia de la acción salvífica de Dios, a través de la gracia. Al respecto y para complementar este pensamiento citamos al teólogo Juan Stam: "La proclamación de una salvación ahistórica y meramente individualista no sólo es un lamentable empobrecimiento del mensaje salvifico de la Palabra de Dios; es malentenderlo y, aunque, sin duda, inconscientemente, ser infieles a la Escritura y al Evangelio".

Los milagros de Jesús siempre tienen la intencionalidad de restaurar a la persona "a imagen y semejanza de quien la creó". Pues todo acto de salvación es humanización y todo verdadero milagro humaniza y restituye el valor y la dignidad a la persona humana; por eso el milagro es un acto auténtico de salvación que tiene 
tanto repercusiones sociales como personales. Podríamos decir que todo verdadero milagro es una nueva creación cuya finalidad es la humanización en Cristo. La meta que Dios ha señalado para la persona es que ésta llegue a ser plenamente humana.

Cuando la gracia de Dios ya haya quitado el pecado, el cristiano puede seguir adelante hasta desarrollar gozosamente todas las facultades que Dios le ha dado. Tal es el humanismo cristiano más alto, un humanismo basado no en el orgullo humano sino en la gracia divina.

Después de lo dicho, afirmamos que vivimos en el milagro y que éste no es un acto mágico y paralizante sino un camino que Dios ha construido, gratuitamente, para que transitemos hacia la dignificación y salvación humanas desde la perspectiva de una realización plena.

Es necesario recalcar que los llamados "milagros físicos", tanto del Antiguo como del Nuevo Testamento y los de hoy, siguen orientando nuestras miradas hacia la Palabra y hacia el Reino definitivo, suscitando la conversión.

"Dios ha querido que en la Iglesia haya, en primer lugar, apóstoles; en segundo lugar profetas; en tercer lugar, maestros; luego personas que hacen milagros, y otras que curan enfermos o que hablan lenguas" (1 Cor. 1 2, 28). Esta jerarquización nos muestra que lo más importante es creer y esperar en la Palabra, la que será transmitida por apóstoles y profetas, preferiblemente; los milagros señalan hacia la palabra y tienen como objetivo potencializarla.

Después de todo lo expuesto, podemos sacar algunas conclusiones que nos permitirán hacer un breve análisis de la devoción a LA NEGRITA, para poder tener claridad sobre lo que le falta y sobre lo que le sobra para estar en armonía con la fe y la vida de María, la mujer madre de Jesús.

María alcanzó en grado sumo la santidad, por ello la llamamos santísima, y el ser santísima es producto de su sintonía plena con la voluntad de Dios, sintonía a la que llega por esfuerzo y trabajo personal. Como cualquiera, tuvo su proceso de maduración en la fe y lo vivió desde una comprensión paulatina del Misterio. Al margen de cálculos y seguridades humanas, aprendió a conjugar lo ininteligible con lo cotidiano. Vivió su entrega a Dios y a la humanidad desde la existencia oscura y rutinaria de cada día. Vivió en el mundo, como quiere Jesús, perteneciendo siempre al Reino de Dios, "no te pido que los saques del mundo, Padre, sino que los protejas del mal" (Jn.1 7,1 5).

María es ejemplo de entrega y desprendimiento; también es modelo de valoración de lo humano, valoración que manifestó desde su vocación diaria de madre, esposa, vecina, y amiga. Hemos dicho que poseer la gracia es igual a tener la presencia de 
Dios, que significa estar en armonía total con Él en el pensar, sentir y actuar. María, "la llena de gracia", recibe agradecida las bendiciones y dones del Señor y los pone al servicio, gratuitamente, de la Vida y del Amor.

Amar hoy, y ayer, y en los tiempos de María, significa comprometerse en la tarea de mejorar el mundo y la calidad de vida de las personas y de todos los demás seres de la creación. Para que ello se realice, es preciso crear la convivencia humana verdadera, la unión y la fraternidad. El amor hoy se llama solidaridad con los más pobres, con los oprimidos y con los que sufren. Es amando como llegamos a ser personas y fue por el camino del amor solidario y gratuito por el que María se encontró con Dios y por el que hace presente a Dios en Jesús, entre nosotros, mientras eleva (cuerpo y espíritu) a la divinidad.

Camino, en sentido evangélico, es sinónimo de seguimiento de Jesús, situarse como discípulo de Jesús de manera creativa y original. Camino y caminata sugieren movimiento, recorrido, alcanzar metas, descubrir lo nuevo detrás de cada recodo; por ello la fe del cristiano no puede ser alienada y desentendida de la realidad. Seguir a Jesús como camino implica dar respuesta en el amor a cada situación, apoyándonos en la esperanza e iluminados por la fe. A ello debería llevarnos la devoción a María.
María se une a Dios por la oración, y no me refiero aquí, como podría pensarse al rezo del Rosario, pues lo encuentro totalmente distanciado de lo que es orar. Hablo de la comunicación íntima con Dios que se da cuando nos abrimos al infinito, no para pedir, sino para conversar, para comunicarnos con Dios en el silencio y en la soledad, desde una profunda preocupación por la vida personal y comunitaria.

Oramos cuando comprendemos que es Dios quien debe hablar, pues nosotros necesitamos oírlo y reflexionar con Él lo que estamos viviendo, los acontecimientos que nos envuelven como miembros de la comunidad mundial y nacional.

Hemos de permitir a Dios que nos inunde con su mensaje, que nos penetre con su Sabiduría, que viva junto a nosotros, como amigos, la existencia. La oración es encuentro con Dios en armonía y preocupación por las y los hermanos. De María hay que aprender su apertura permanente a la comunicación con Dios, sin por ello abandonar sus acciones cotidianas. La oración es fuego; fuego quiere decir transformación. (Anthony de Mello, Caminar sobre las aguas).

La oración, así entendida y vivida, se convierte en camino de transformación y, para que esa transformación entre en armonía con la voluntad de Dios, es preciso ver de otra manera, de una manera nueva. "Es necesaria la buena voluntad 
para pensar en lo que no es habitual, buena voluntad para ver algo nuevo (Anthony de Mello, Caminar sobre las aguas).

Hemos dicho que María es la mujer fiel a Dios desde su vida sencilla y cotidiana, que aceptó con entereza los acontecimientos de su vida y la de Jesús: el gozo y la alegría en el nacimiento de su Hijo y la visita de los pastores y de los Magos, el destierro como familia, la vida como refugiados, las ternuras y travesuras de la niñez de Jesús, el acompañamiento a Jesús en su predicación, junto con otras mujeres, solidarizándose junto a la cruz del amado hijo y luego, como compañera, animando a las y los discípulos de Cristo.

Y todo ello nos lleva a decir que fue una mujer de fortaleza pero no a afirmar que fue la mujer fuerte que nos animan a ser a las mujeres, desde una concepción patriarcal más cercana a la visión de la "Mujer Maravilla", expresada en Proverbios 31,1031 , texto con el que se manipula a las mujeres para ser la "PERFECCION" desde la conveniencia del varón y de la familia, sutil forma de convertirla en un ser "para" que no tiene nada para sí misma, en un ser desértico de sí.

La mujer fuerte, según ese texto, es aquella ahogada por el trabajo, sin tiempo para ser ni para disfrutar, es la mujer de la eficiencia neoliberal subyugadora. Este texto me hace recordar a tantas campesinas agobiadas y negadas, como personas, por un trabajo alienante. María no fue una mujer fuerte, sino una mujer valiente cuya fortaleza brotaba de su fe y confianza en Dios y en sus hermanos (as). Esperamos que este telón teológico de fondo nos permita ver, desde una visión liberadora, la devoción a la Virgen de los Ángeles.

\section{La devoción de La Negrita, dentro de la religiosidad popular}

La religiosidad popular es una parte del fenómeno religioso. Es sumamente complejo definir el fenómeno religioso, por cuanto las líneas que lo separan de la magia, en la vida práctica, a menudo se pierden o se desdibujan. Por otra parte, mantener la especificidad y originalidad de dicho fenómeno es también complejo. Para efectos de esta reflexión lo vamos a entender como un sistema de creencias, actitudes y actividades que responden a la necesidad humana, específica, de encontrar el sentido de la vida.

Además, hemos de tener presente que su contenido humano específico posee un nuevo significado que es teológico: ser una semilla de la palabra de Dios, en el sentido de una verdadera revelación de Dios a sus hijos e hijas. Al respecto El Concilio Vaticano II, en su decreto sobre la actividad misionera de la Iglesia, pide a los católicos (as) en relación con las tradiciones religiosas de otros 
pueblos, que "descubran con gozo y respeto las semillas de la palabra de Dios, que en ellas se contienen." (Ad gentes, n. 11).

De esta manera la Iglesia reconoce, en otras formas de fe, tanto a la palabra del ser humano que busca a Dios, como la palabra de Dios que busca al ser humano y, como afirma Manuel Marzal, "el fenómeno religioso no sólo es un hecho "original", sino que también puede considerarse como un "hecho divino", pues entraña una cierta presencia y actividad de Dios" (Marzal 1973: 14).

Definir la religiosidad popular es dificultoso, por ello señalaremos, simplemente, que puede decirse que la religiosidad popular es la manera como se expresa religiosamente el pueblo, como masa con escaso cultivo religioso. Es la religión del "hombre de la calle". Es la religión de las mayorías que a menudo se oponen a la religión de las minorías oficiales e ilustradas, teológicamente hablando. La religiosidad popular es una verdadera cultura, un modo de pensar, de actuar y de sentir en el campo religioso de un grupo humano específico. Se transmite por el proceso de la socialización, generalmente, por canales informales, como parte de la cultura nacional.

Toda forma concreta de religiosidad popular selecciona, de acuerdo con el contexto histórico cultural, formas religiosas específicas (procesiones, peregrinaciones, visitas a sitios sagrados, "la pasada", etc.).

La religiosidad popular, además, realiza una reinterpretación de las formas religiosas oficiales, cambia, aumenta o quita significados y funciones "el pueblo no inventa, aumenta", (A. Soria + , comentario en una tertulia de la Escuela Ecuménica de Ciencias de la Religión de la UNA. Primer director).

Además, es considerada como marginal por la importancia que da a lo accidental, $\mathrm{y}$, sincrética, pues en sus contenidos conserva creencias y comportamientos de orígenes diversos. Las leyendas y los mitos son narraciones que han sido diversamente interpretados (escuela histórica, funcionalismo, estructuralismo), $\mathrm{y}$ desempeñan múltiples funciones de sentido en los grupos humanos.

Sin duda sólo mediante el conocimiento amplio de los mitos, podemos llegar a un profundo conocimiento de la humanidad. El mito, como relato oral que es, en su génesis, es como dice Lévi Strauss "un lenguaje pre-semiótico en el que lo gestual del rito, del culto, de la magia es antes que la gramática y el léxico" (Strauss 1995), apunta a la realidad numinosa, como afirma José Camblin: "en el mito estamos buscando un modo de experimentar el mundo que nos abre a lo trascendente, a lo que da vida al mundo y al mismo tiempo nos forma dentro de él" (Camblin, S. F.). 
Desde estas expresiones podemos decir que el mito se convierte en un instrumento excepcional en la búsqueda del sentido profundo. Para enriquecer lo dicho citamos a G. Durand: "Es (el mito) el relato que lleva incrustadas secuencias dramáticas y símbolos, que pone en escena unos personajes y unos decorados, que revaloriza simbólicamente una serie de objetos, al servicio de la integración de los insoslayables antagonismos de la realidad y de la vida. El mito se sitúa así del lado del sujeto más que de la logicidad objetiva, del espesor a menudo ambivalente del discurso poético." (en Campos 1973)

El mito nos abre a las formas del misterio, presentes en el mundo, por ello, dice, J.M. Mardones que "es el vehículo que nos pone ante el misterio de lo sagrado". (J.M.Mardones, Para comprender las nuevas formas de la religión. La reconfiguración del cristianismo)

La mayoría de las formas religiosas populares cumplen también otras funciones (sociológicas, económicas, sociales, culturales, etc.), además de las específicamente religiosas. Un claro ejemplo son las fiestas patronales y las apariciones de la virgen y de los santos.

Como dice Alfonso Chase, en su libro Nuestra Señora de los Ángeles:

"para lograr entender la vigencia del culto, y significado de la imagen de la Virgen de los Ángeles en la vida nacional, se hace necesario enmarcar el hecho tradicional dentro de los marcos de la religiosidad popular, desde la fecha de su aparición hasta el momento presente.

Son más de trecientos cincuenta años de plena vigencia y unidad, en un culto que primero perteneció a un barrio o pueblo, luego pasa a nivel provinciano, hasta determinar una expansión nacional. Los elementos de la religiosidad popular se encuentran en la tradición oral, los testimonios religioso- sacramentales del culto, las crónicas literarias y, a partir del siglo XX, en documentos y legados propios del desarrollo del espacio civil y religioso de nuestro país."

\section{María en América Latina}

En el proceso histórico de América Latina existe un acontecimiento "teofánico" germinal, un acontecimiento liberador, si bien envuelto en la ambigüedad propia de nuestras incipientes culturas: el primer encuentro de nuestros pueblos con Dios, sinónimo del encuentro de Dios con Moisés. Un encuentro de liberación.

Es importante por ello preguntarse ¿qué significa para la historia de América Latina, que en sus albores se diera el acontecimiento teofánico de cara a cara entre la Virgen y el indio? El Canto de María (magníficat) manifiesta el espíritu de liberación y de 
misericordia hacia los más débiles y los más pobres, por parte del Señor. Además manifiesta la promesa de Dios de hacerles justicia.

Como hemos dicho, María se compromete con los pobres de Yahvé y es su mediadora. Por ello la aparición de la Virgen de Guadalupe al indio Juan Diego se enmarca, como acto teofánico, en la promesa de liberación y salvación de Dios a su pueblo que, como el indígena, estaba esclavizado.

Raúl Vidales afirma que:

"el significado más profundo estaría en una doble vertiente: primero, sería la explicitación dentro del proceso histórico de América Latina del elemento "liberador" que marcaría el momento de ruptura con una experiencia pagana. Pero al mismo tiempo esto significaría "la semilla histórica de liberación" en América Latina, que irá como un proceso de crecimiento y maduración hasta el momento actual que se está denominando como el momento de salvación para nuestros pueblos", "el tiempo de nuestra redención; "la hora de nuestra liberación." (Vidales 1973: 75)

La Guadalupana (María) afirma tanto con su aparición, como con su mensaje verbal, que los predilectos de Jesús son también los suyos:

"Deseo vivamente que se me erija aqui un templo para en él mostrar y dar todo mi amor, compasión, auxilio y defensa, pues yo soy vuestra piadosa madre, a ti, a todos vosotros juntos, los moradores de esta tierra y a los demás amadores míos que me invoquen en mi confin; oir alli sus lamentos, y remediar todas sus miserias, penas y dolores". (Vidales 1973)

Estas palabras de María son proféticas y evangélicas. Se insertan en la visión solidaria y amorosa de Jesús y de su Padre. Por otra parte, el mensaje corresponde al estilo de la religiosidad popular: un marginado que tiene un grave problema, a quien la venerada imagen ayuda milagrosamente, después de pedirle algún sacrificio.

Es también necesario recalcar que el encuentro de María y Juan Diego (indio) se da cuando aún no hay fronteras en el continente, cuando somos una sola América y dentro de una raza pisoteada....Esta es la experiencia de fe, liberadora germinal de nuestro Continente. Este hecho fundante se ha repetido en todos los países de América.

$\mathrm{Al}$ respecto es interesante conocer lo que nos dice Alfonso Chase en su libro citado:

"La colocación de nuestros pueblos bajo una imagen determinada, y regional de la Virgen María, con historia propia y afirmación de leyendas autóctonas, buscaba, no sólo sustituir la imagen española por una nacional, sino también profundizar en una consciencia criolla, 
o mestiza, que revalorara el culto hasta hacerlo propio de nuestras tierras." (Chase 1995)

Dentro de esta teofonía y de estas circunstancias culturales y políticas se da, también, la aparición de la Virgen de los Ángeles.

\section{La devoción de La Negrita entre la religiosidad popular, la magia y la teología}

Hemos situado la aparición de la Virgen de los Ángeles dentro del hecho teofánico de la aparición de la Virgen de Guadalupe. Es, por así decirlo, una variación nacional de ella. Debemos, también recordar que un indiscutible valor de la religiosidad popular radica en que es una manera particular por la que trata de comunicarse el pueblo con Dios, a pesar de que dicha religiosidad esté condicionada por factores culturales, ambientales, políticos, socio-económicos e históricos que, a menudo, impiden la evolución paulatina de esa misma relación.

También es preciso afirmar que un peligro serio de la religiosidad popular lo constituye su facilidad para caer en la magia. Aunque la ciencia social ha encontrado criterios definitivos para separar la religión de la magia, sí podemos hablar de "orientación" de los fenómenos, hacia la una o hacia la otra.
"Los fenómenos que entrañan una manipulación de lo sagrado hacia fines utilitarios, por un especialista, al margen de la comunidad, para controlar ciertas fuerzas naturales con independencia del comportamiento personal, puede decirse que tienen una "orientación mágica". En cambio, los fenómenos que entrañan súplica a los poderes sagrados, que son celebraciones más que utilitarias, por la comunidad de creyentes y con un claro compromiso personal, puede decirse que tienen una "orientación religiosa" (Manuel Marzal, Ibid).

La religiosidad popular de nuestro pueblo es pobre en elaboración teológica, y a veces contradice, abiertamente, los principios teológicos; es el caso de beber el agua de la Virgen para sanar algún mal. Esto equivale, más a un acto de magia que otorga "poderes milagrosos a un elemento natural". También nuestra religiosidad popular es pobre en contenido histórico. La mayoría de las veces este contenido se halla completamente ausente.

\section{Análisis de la devoción a La Negrita}

Para analizar la devoción de la Negrita estableceremos relaciones entre la devoción con la teología y con la religiosidad popular y la relación de ésta con la magia. Anteriormente, hemos desarrollado, teológicamente, una visión de María 
como persona y de su relación con Dios y con Jesús. También hemos señalado las características principales de la religiosidad popular.

Antes de iniciar el análisis de la devoción quiero aclarar que soy devota de la Virgen María y que valoro la religiosidad popular, lo que no es impedimento para ofrecer una visión crítica de la devoción a la Virgen de los Ángeles.

Es muy significativo, religiosamente hablando, referir que la devoción a la Negrita se inicia en un espacio sagrado, como toda manifestación de irrupción de lo divino en el mundo; es el inicio de un diálogo entre Dios y su pueblo.

Este espacio se convierte, simbólicamente, en un lugar propicio para el culto. Esta concepción pertenece a la religiosidad popular y teológicamente se encuentra en contraposición al decir de Jesús:

"Créeme, mujer que llega la hora en que ustedes adorarán al Padre sin tener que venir a este monte ni ir a Jerusalén(...) Pero llega la hora, $y$ es ahora mismo, cuando los que de veras adoran al Padre, lo harán de un modo verdadero, conforme al Espiritu de Dios. Pues el Padre quiere que así lo hagan los que lo adoran. Dios es Espiritu, y los que lo adoran deben hacerlo de un modo verdadero, conforme al Espiritu de Dios" (Jn. 4-21 , 23, 24)
La devoción enseña a tener respeto por la piedra en que apareció la imagen y es, además, señal histórica espacial del acontecimiento. La mayoría de los devotos así lo entienden; sin embargo, los más ligados al pensamiento y visiones mágicas pasan la mano por la piedra en busca de favores o bendiciones; nuevamente, pensamiento mágico y religioso se entremezclan.

La imagen en piedra negra de la Virgen de los Ángeles representa a una joven indígena con un bebé pequeño, indígena, igual que ella, en los brazos. Pero, más allá de su forma estética se encuentra su significación étnica: es una indígena, una mulata o una criolla, no es blanca, ni europea, sino representación de los pueblos "inferiores y esclavos" de nuestro Continente. Su color negro ha sido interpretado, religiosamente, como signo de identificación con los hombres y mujeres de piel oscura de nuestro País, por ello marginados.

La imagen también nos señala la búsqueda de relaciones más justas entre los blancos, los cholos y pardos; apela a levantar a los caídos mediante la presencia de Dios en su niño Jesús. Invita a vivir en mayor fraternidad y a establecer relaciones menos verticales, al decir desde la imagen, que ella es una de los y las excluidos (as). Manifiesta la gratuidad de Dios para con los y las humildes y hace explícito, una vez más, el deseo de María de permanecer en medio de 
los pobres para redimirlos, deseo que está en consonancia con el espíritu del Magníficat.

¿Por qué, entonces, recubrir a la imagen con oros y piedras preciosas? Pareciera que hay una limitación convertida en prejuicio y en tradición, para no aceptar la sencillez y la humildad en todo aquello que nos viene de Dios. Es querer hacer prevalecer la imagen falsa del dios, rey poderoso, dueño de todo y cuya ostentación es su signo de poder, al estilo humano.

En su imagen, se la ha atrapado en oros y lujos, no se la deja libre de movimiento para ir a los pequeños; ellos huirán de ella ante tanta ostentación que acrecienta las diferencias entre ricos y pobres. Quieren borrar el significado de su preferencia por los pobres y humillados, al tapar con vestidos, coronas y aureolas sus sencillas vestiduras y sus facciones indígenas.

Pareciera que quieren callar, de una vez por todas, el mensaje y el espíritu liberador del magníficat y restarle, así, valor al hecho teofánico. Además se convierte la visión estética en visión ridícula. Pareciera que hay un mensaje, de los administradores de la devoción, para Dios y María, en el sentido de obligarlos a ocupar su lugar divino, según los gustos humanos. Pareciera que consideran necesario enmendarle la página al Dios humilde y sencillo, identificado en todo con los pobres y oprimidos, para que ocupe su lugar de privilegio, el lugar supremo de Dios poderoso, según la lógica humana, la cual se aparta totalmente de la lógica de Jesús y de nuestro Padre.

Es manifestación del orgulloso deseo de enmendarle la página a Dios, sacándonos del Misterio Divino de la humildad y de la fraternidad. Es construir barreras que impidan descubrir la misericordia y mansedumbre de Dios. Es poner las cosas "al derecho", porque Dios las hace "al revés".

El hecho de variar, intencionalmente, la imagen de la imagen apunta, además, a un hecho inmoral de adulterar el mensaje claro y diáfano de María, al convertirlo en un mensaje ambiguo que niega el verdadero espíritu de la comunicación de María con Juana Pereira y todos y todas sus iguales. ¿Será por ello que aún las mujeres indígenas con las que se identifica desde su figurita negra, no han alcanzado, en Costa Rica, su verdadera dignificación como personas?

Es preciso volver a la imagen original y a su mensaje liberador. Esta visión ambigua de María en la imagen acicalada de La Negrita ha imposibilitado que la fuerza de su palabra rompa el corazón de piedra de la cultura patriarcal y sus afanes de dominio y colonización. Debemos recordar que la devoción de María nunca ha de estar separada del culto y del amor a Dios y, algo más importante 
aún, ha de ir en consonancia con el amor de Dios.

Desde la devoción a la Virgen María, modelo perenne de amor y entrega , el cristiano (a) debe estar referido a vivir una fe abierta y progresiva, modelo indiscutible de vivir la condición femenina, vida evangélica y liberada, participación activa en el mundo, actitud fiel de servicio, testigo de la acción salvadora y del amor de Cristo.

¿Están posibilitados (as) los y las devotas de la Virgen de los Ángeles, para vivir y creer así? Lo que comúnmente vemos y oímos es un discurso, más parecido a un negocio (me das y te doy) que la referencia a un compromiso de construcción del Reino de Dios en donde desaparezcan el dolor, el pecado y la muerte.

Al respecto transcribimos la expresión del Papa Paulo VI, recogida por el Concilio Vaticano II en Lumen Gentium, número 54: "Se exalta, de un lado la dignidad y excelsa función de María, para honrarla como es debido, y por otro, se pone de relieve su cercanía a nosotros. Su función maternal nos habla de ternura, acogida, protección y socorro seguro hacia nosotros. En correspondencia, nos sugiere confianza total y amor, expresados en una devoción sincera y madura, sencilla e ilustrada, entusiasta y fiel".

La evolución de la fe, aquí referida, ¡cuán lejana está de las mayorías devotas de la Negrita Reina de los Ángeles!, título que la aleja del pueblo, corona de reina terrenal, con piedras preciosas y oros. Corona que pesa mucho más que ella y que oculta su sencilla y humilde cabeza. María de Nazaret nunca soñó ni anheló una corona, ni un título. Entre las pocas palabras reseñadas por los Evangelios dichas por María, aparece su declaración de ser "La esclava del Señor". Se sitúa así en el lado de los que nada tienen y nada se reservan, entrega hasta su voluntad personal, por voluntad propia. Es la culminación práctica y real de la pobreza de espíritu, según el Evangelio, nada se reserva para sí.

Todo reinado terreno coloca al ser humano frente a las tentaciones del poder, el dominio y las riquezas. María rechazó todas esas tentaciones, voluntariamente, ¿entonces por qué la Iglesia la declara Reina y le proporciona objetos que la hacen parecer como tal? Estamos de nuevo ante la ambigüedad que se origina en la manipulación del mensaje, en la ambigüedad que ha llevado a hombres de carne y hueso a la cárcel por haberse apropiado de algunas ostentadoras riquezas impuestas a la imagen. Pablo en la primera carta a Timoteo, capítulo seis, versos del seis al doce:

"Hay quienes piensan que la piedad es un negocio; la piedad es ciertamente un buen negocio cuando uno se conforma con lo que tiene; porque nada trajimos al mundo, como nada podremos llevarnos, así que 
teniendo qué comer y con qué vestirnos, podemos estar contentos. Los que quieren hacerse ricos, caen en tentaciones, trampas y mil afanes insensatos y funestos, que hunden a los hombres en la ruina y en la perdición; porque raíz de todos los males es el amor al dinero; por esta ansia algunos se desviaron de la fe y se infligieron mil tormentos.

Tú, en cambio, hombre de Dios, huye de todo eso, esmérate en la rectitud, la piedad, el amor, la constancia, la delicadeza. Lucha en el noble combate de la fe, conquista la vida eterna a la que fuiste llamado: de esa fe hiciste noble profesión en presencia de muchos testigos."

Meditando estas palabras me pregunto, ¿por qué entonces transformar a María en una mujer rica e importante, si ella se denomina esclava y si su deseo es permanecer entre los y las pobres? ¿Existe alguna reina pobre?

"Nadie puede servir a dos amos, porque odiará a uno y querrá al otro, o será fiel a uno y despreciará al otro. No se puede servir a Dios y a las riquezas." (Mateo 6: 24)

Volvemos a lo dicho sobre la manipulación al mensaje de la Negrita, manipulación que nos aleja de la verdadera fe, a la vez que se convierte a María en lo que ella rechazó, i podrá verse testarudez mayor!...
María pone su seguridad, no en el poder y el dinero, sino en Dios, el que mira con misericordia a los y las de abajo. Hace cerca de treinta años, el presbítero y teólogo Carlos Joaquín Alfaro Odio nos enseñaba que ser rey, bíblicamente hablando, significa "ser quien más sirve", y para ello no es preciso ostentar ni poderes ni riquezas. Al respecto es necesario recordar la respuesta de Jesús a la madre de los zebedeos y a sus discípulos, cuando ella le pedía para sus hijos el lugar de la derecha y de la izquierda de Jesús, como signo de honor.

"Como ustedes saben, entre los paganos los jefes gobiernan con tiranía a sus súbditos, y los grandes hacen sentir su autoridad sobre ellos. Pero entre ustedes no debe ser así. Al contrario, el que entre ustedes quiera ser grande, deberá servir a los demás; y el que entre ustedes quiera ser el primero, deberá ser su esclavo. Porque, del mismo modo, el Hijo del hombre no vino para que le sirvan, sino para servir y para dar la vida en rescate por una multitud." (Mateo 20: 25-28)

Así pues, queda claro que si María es reina es porque es esclava y servidora. ¿Acaso no desvirtúa esta realidad colocarle coronas y otorgarle títulos nobiliarios, propios de la sociedad humana? ¡Cuánto pesa esa corona en el avance de la verdadera fe de sus devotos y devotas! Otro título que se le da es el de Patrona de Costa 
Rica. Para tener claridad sobre la posible génesis de este título tenemos que irnos hasta el tercer milenio antes de Cristo, de la época clásica sumeria de Mesopotamia. Mesopotamia estaba entonces organizada en un sistema de ciudades-estado, en su mayoría muy pequeñas. La ciudad -estado era una teocracia gobernada por el dios; la ciudad y los terrenos eran propiedad del dios.

Los miembros del pueblo eran los jornaleros del dios, trabajadores de su propiedad.

La primera cabeza del Estado era el "lugar" (gran hombre) el rey o el "ensi" sacerdote del templo local que gobernaba como el virrey del dios, el gerente de sus propiedades, Este segundo personaje podía ser o bien el señor de una ciudad independiente o bien un vasallo del lugar, en otra ciudad.

Esta costumbre se fue extendiendo a otros pueblos y generó diversas formas de protectorados y patronatos. En la iglesia cristiana, la costumbre de invocar a determinados santos (as) como patronos (as) o protectores de naciones, ciudades, individuos, se remonta a los primeros siglos; y a otras religiones, como la romana, contaban con dioses protectores de ciudades y de familias (los dioses familiares), posiblemente inspirados, también, en ideas religiosas mesopotámicas y sumerias.

Más tarde, en la iglesia cristiana, se introdujo la costumbre de escoger, como nombre propio, el de algún santo (a) venerado (a) por la Iglesia. En el siglo XVII el papa Urbano VIII dispuso que en adelante la elección de santos patronos nacionales o locales, debería ser ratificada por la Santa Sede. Anteriormente, los patronos de los diversos lugares eran designados por tradición popular. Las iglesias y diócesis tienen sus patronos (as) que se llaman santos tutelares de la Iglesia o diócesis.

Dentro de la religiosidad popular la celebración de la fiesta del santo patrón tiene el significado de recalcar la seguridad de protección de parte de alguien superior que tiene poder para ayudar (sentimiento mágico). También el patrono es un modelo de imitación, por parte de los miembros de la iglesia de la cual es protector.

Sin embargo, dentro de la religiosidad popular el día del patrono es, únicamente, ocasión de fiestas y regocijos populares, y se olvida su significado como modelo. Sus seguidores (as) le hacen peticiones y le ofrecen promesas con tal de que les conceda el favor pedido. Se establece una relación de intercambio “interesado' que en nada encamina al creyente a crecer o a profundizar en su vivencia de fe. Según la teología oficial la fiesta del santo patrono tiene sólo una función cúltica y según la religiosidad popular, tiene también funciones de integración social, de desahogo colectivo, de 
promoción por el prestigio, y hasta de nivelación económica.

Como podemos concluir, el hecho del patronato tiene, como carácter especial, el histórico y el socio político. A la religiosidad popular la empobrece, pues vuelve a reproducir la estructura piramidal del poder patriarcal y en la mente de los creyentes lo que prevalece es el símbolo de que existe alguien superior que es quien manda y por lo tanto a quien hay que obedecer, acríticamente.

Es una visión subyugadora, igual a la de Reina, le da la espalda al deseo de Jesús de que todos y todas seamos hermanos verdaderos, que no haya nadie superior al mando.

El espíritu de la hermandad se expresa en la solidaridad y el mutuo y desinteresado (gratuito ) servicio. Por otra parte, esta visión de patrona hace que, a nivel sensible, todas las personas que participan de la devoción se sientan, a nivel emotivo y psicológico, como "jornaleros" (as) de la Negrita -patrona. En los últimos tiempos, igual que en anteriores, el sentido mágico de protección, ha enriquecido el mito de que ella, La Negrita, protege a Costa Rica, aún desviando huracanes, como el Juana, hacia pueblos "menos buenos" que el costarricense.

Por ser nuestra patrona y reina, los deportistas, y en especial los futbolistas, llevan la imagen a los partidos para que los proteja y les dé el gane, reforzando así las ideas míticas del panteón griego, en el que los dioses y diosas tomaban partido, tanto en las guerras como en los juegos. Y, con estas prácticas (ritos) se incrementan visiones mágicas de la vida. Y, ¿acaso la imagen no se convierte en amuleto de la suerte, o en algo semejante?

Hablar de la Virgen y de su acción mediadora desde prácticas mágicas como las señaladas, convierte a nuestra Señora en una milagrera y nos aleja del real sentido de milagro y de mediación derivados del mensaje salvador de Dios, tanto en el Nuevo como en el Antiguo Testamento. Pero, lo más dañino, quizás, para la fe cristiana, derivado de los títulos terrenales otorgados a la Negrita, lo constituye su participación como "Capitana, de la fuerza pública de Costa Rica", de un país sin ejército y en el que están prohibidos los grados militares.

Dentro de la devoción se la considera como peregrina y la imagen es llevada a todas las diócesis. Al respecto ofrecemos unas citas, tomadas del libro citado de Alfonso Chase, Nuestra Señora de los Ángeles, para ilustrar lo dicho y ofrecer luego, nuestro análisis crítico.

"1824: 23 de setiembre. El presidente de la Asamblea Constituyente, Licdo. don Agustín Gutiérrez propone, y la Asamblea aprueba por unanimidad, que la Virgen de los Ángeles, no la imagen, Madre de Dios y Señora nuestra, es y será en 
lo sucesivo, la Patrona del Estado de Costa Rica. El 24 de setiembre, Juan Mora Fernández, nuestro Primer Jefe de Estado, rubrica el decreto emitido por la Asamblea. (Chase 1995: 57)

1835: el 14 de octubre, como consecuencia del asalto de las tropas cartagineses a las de las otras ciudades: Alajuela, Heredia y San José (Guerra de la Liga), los cartagos dejan abandonada en Curridabat una imagen de Nuestra Señora de los Ángeles, llamada la Peregrina, la cual es enviada y depositada, con grandes honores por el vencedor, don Braulio Carrillo, a la Iglesia de la Merced, para que se le pusiera en un altar que designara el cura. (Chase 1995: 59)

1842: vecinos $y$ autoridades de Cartago solicitan se les devuelva la imagen de la Virgen de los Ángeles (La Peregrina) . La petición tiene fecha 8 de julio y se presenta como un memorando al Jefe de Estado. El General Jefe Supremo Provisorio del Estado, Francisco Morazán, ordena al General José Miguel Saravia que entregue la imagen al cura de Cartago para que "este acto de concordia borre hasta el último testimonio de los pasados disturbios de ambas poblaciones, contemplando la obra de su franca y sincera reconciliación. (Chase 1995: 59)

1928: en notable estudio, publicado en el Mensajero del Clero, Monseñor Sanabria explica $y$ analiza el significado político $y$ regional y militar de la Virgen de los Ángeles, en la Guerra de la Liga, su carácter de trofeo militar y la manipulación de Carrillo al tributarle homenajes, en una hora coyuntural en nuestro desarrollo republicano. (Chase 1995: 62)

1950: el 26 de febrero la Virgen de los Ángeles, con motivo de la celebración del centenario de la Erección de la Diócesis de San José, visita la Catedral. Se trataba, según el pensamiento de Sanabria y Martinez, de lograr la unificación de la familia costarricense, luego de la Guerra Civil de 1948. Reitera la idea de su culto como unidad y paz. (Chase 1995: 64)

1984: con motivo del V Sínodo Arquidiocesano, se preparan jornadas de devoción mariana, que coinciden con la traída, por algunas horas, de la imagen de Nuestra Señora de los Ángeles a San José, donde se le tributan honores en el Estadio Nacional, en las jornadas sinodales, presididas por Monseñor Román Arrieta en diciembre de ese año. (Chase 1995: 65)

1985: con motivo del 350 aniversario del hallazgo de la imagen, se dispone la visita a todas las Diócesis de Costa Rica de Nuestra Señora de los Ángeles, a partir del 22 de junio de este año. La visita se extiende por todo el territorio nacional, con singular despliegue de devoción y de cariño por parte del pueblo católico. La Virgen viaja en el papamóvil $y$ helicóptero por todo el territorio 
nacional, y recibe, el 2 de agosto, la mayor concentración de fieles en su historia." (Chase 1995: 65)

Las anteriores citas demuestran cómo se ha manipulado, en estos 300 años, la devoción de la Virgen de los Ángeles por parte de políticos y eclesiásticos. Lo citado, además, pone de manifiesto la incidencia de la religiosidad popular en aspectos históricos, políticos, económicos y culturales.

La manipulación referida distorsiona la figura evangélica de María y convierte a la esculturita en un juguete en manos de la imaginación religiosa de los clérigos y de los devotos (as) que la tratan como si fuera persona, o una muñequita en manos de una pequeña niña que la viste y desviste a su antojo. También, con acciones como éstas se pierde la potencia profética del hecho de fe, pues es en la impotencia y en el desvalimiento donde se da la acción liberadora del Espíritu, según la Revelación y el Evangelio (y no puede ser desvalida quien usa tales medios para su transporte, medios imposibles para la mayoría de las y los creyentes).

La aparición de La Negrita, como acto de fe, es anuncio y a la vez reto para construir una fraternidad popular, de todos "los moradores de estas tierras", como dijo Nuestra Señora de Guadalupe, y como lo evidencia el mensaje escultórico étnico de La Negrita. Pero la fraternidad, o la "concordia" del pueblo no puede dependerdelas peregrinaciones de una imagen, cuando lo que se necesita es trabajo y compromiso de los hombres y las mujeres de carne y hueso en la construcción del Reino de Dios.

Creer en "poderes" de una imagen es pensamiento mágico, no fe en el Dios de la Vida y del Amor, el Dios de Jesús. Una devoción vivida con tantos elementos exógenos (mágicos e interesados) a la fe verdadera en el Señor Jesucristo, muerto y resucitado, impide el crecimiento y la liberación de quienes recurren a La Negrita esperando verse libres de todas las esclavitudes y penas. Además, estas acciones y visiones míticas impiden el recorrido de un itinerario hacia una fe cada vez más personalizante.

Para mí, desde una visión de fe verdaderamente cristiana, todos estos actos son realmente paganos y hacen perder fuerza a la búsqueda de Dios en Espíritu y Verdad. Estos hechos concretos ponen de manifiesto que esta "religiosidad popular" derivada de la devoción a La Negrita, comunica a los creyentes imágenes de Dios y de la religión, falsas y rechazables.

\section{La peregrinación del 1 de agosto, la pasada y los exvotos}

Para poder hacer una reflexión sobre estos aspectos, es preciso recordar que son lenguaje, que comunican, que significan. El lenguaje es una institución social, donde cada palabra, cada 

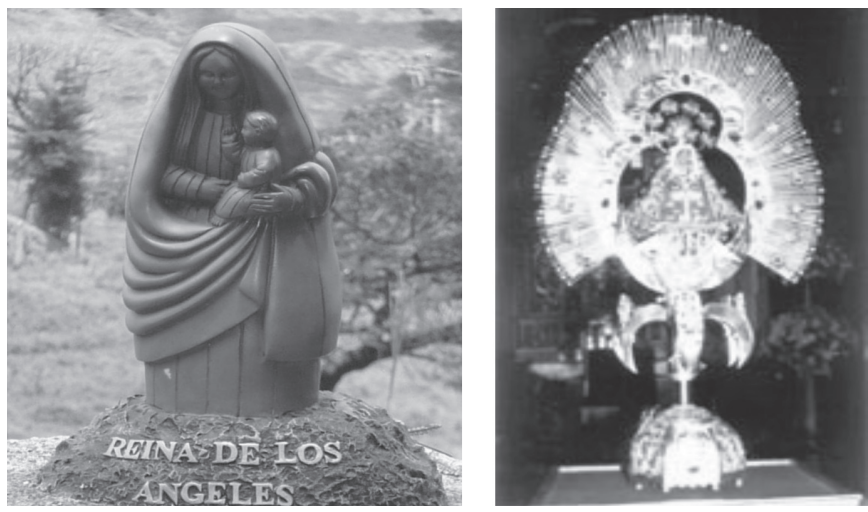

símbolo, cada gesto, es coherente en el sistema total, de ahí que todo cambio de la palabra, del símbolo, o del gesto depende de cambios previos de la mentalidad y de la cultura.

Desde el punto de vista pastoral, no se pueden hacer adoptar, por el pueblo creyente, nuevos símbolos o palabras que expresen nuevos valores, sin propiciar la adopción de ellos desde una nueva toma de conciencia. "Una nueva simbología y lenguaje religiosos forman una nueva mentalidad y cultura religiosa popular" (Galilea, 1985).

El lenguaje religioso es una forma de "lenguaje especial", que tiene como una de sus funciones dar expresión al catolicismo de multitudes. Produce una fuerte unión emocional profunda, realizada con pocas ideas sencillas, que se han convertido, para el pueblo creyente, "en imágenessímbolos significativos" (Segundo

Galilea, Ibid). El lenguaje religioso, como todo lenguaje, posee sus propias leyes y su propio código lingüístico, es interpretativo y dialógico, por ello induce a actitudes y comportamientos específicos. Crea un acercamiento y afinidad entre Dios y la persona humana.

"Como este diálogo tiene a un interlocutor invisible, se valdrá, más que cualquier otro lenguaje, de símbolos que encarnen a este Dios y mundo invisibles" (Segundo Galilea, Ibid). El lenguaje religioso es, al mismo tiempo, vehículo de conocimiento y comunicación de una determinada imagen de Dios. También expresa el tipo de relación entre el pueblo creyente y Dios; por ello es fruto y causa de una mentalidad religiosa concreta.

Lo expresado tiene implicaciones críticas que deben ser asumidas por la teología, pues de lo contrario, como fruto, tendremos 
una mentalidad religiosa alienada y mítica, en franca contradicción con la Revelación y el Evangelio y sin posibilidades de cambio. Tanto la romería del 1 de agosto, como la pasada y los exvotos, obedecen a concepciones religiosas pre-conciliares, que tienen influencia de la religiosidad popular judía (circuncisión, peregrinación anual al templo, la Pascua, etc.), y obedecen a prácticas religiosas contaminadas por "creyencerías" originadas en acciones profanas cercanas al esoterismo o claramente esotéricas (dominio de las fuerzas de la naturaleza para someterlas en los momentos de necesidad y urgencia).

La búsqueda del sentido de la vida es el motor que ha impulsado a la humanidad a introducirse en lo misterioso y en "lo oscuro". En el fondo está la cuestión del destino, y unido a su fascinante y terrible oscuridad, se encuentran la suerte y el azar. En unión con ello anida el deseo de poder manipular al destino, el que para la mayoría de las personas tiene sabor sagrado, divino.

Por ejemplo, para la mayoría de los y las creyentes, la enfermedad es enviada por Dios, como castigo o como prueba; entonces, mediante rezos, ofrecimientos, penitencias, escapularios, novenas, exvotos, agua de la fuente, algodones con los que se ha limpiado la imagen, etc. se pretende persuadir y a veces "obligar" a Dios a cambiar "sus designios" y a devolverle la salud a la persona enferma.

Esta es una convicción general de las y los católicos de nuestro país. Los exvotos son formas concretas de agradecer a la Virgen su intercesión y son parte de la promesa del creyente. Sin embargo, este mismo signo de agradecimiento y promesa está en contradicción con la gratuidad de todo cuanto nos da y hace Dios por nosotros. Jesús nos enseña que "no quiere sacrificios sino que quiere misericordia" y que debemos adorar y glorificar a Dios en espíritu y verdad. $Y$ en la peregrinación priva el sentido de promesa y sacrificio, para obtener una gracia o un milagro, y a cambio se hacen ofrecimientos.

Es importante escuchar a los peregrinos decir que vinieron a la romería para pagar una promesa. Esta expresión nos coloca frente a una transacción mercantil, no frente a una relación de acción de gracias en el sentido evangélico. A la luz de la reflexión teológica realizada, esta costumbre de hacer promesas a María y de pagarlas, está en contra del hecho teológico de que quien hace las promesas es Dios, así como del espíritu de donación y gratuidad divinos, compartidos y vividos por María.

En cuanto a los milagros, entendidos desde la devoción a La Negrita, hemos de decir que se distorsiona tanto su concepción bíblico-teológica, así como la misión de Mediadora de María, según queda explicitado 
en este escrito. Los milagros se convierten en actos, en alguna forma de magia y están ligados a alguna expresión ritual y a elementos y objetos con "poderes (hacer una novena, rezar determinada oración, colocarse algún escapulario tomar agua de la fuente, pasarse un algodón después de que con él se haya limpiado la imagen el 1 de agosto), capaz de convencer a Dios, por medio de María, de que debe cambiar su "voluntad", y así voluntad de Dios y destino se comprenden como sinónimos.

Estas concepciones, además, expresan una visión de persona sin libre albedrío e incapaz de tomar sus propias decisiones y de construir su "propio destino".

Realizando acciones como las señaladas se imposibilita al pueblo creyente para saber y vivir que "la liberación del ser humano en Jesucristo sólo es fruto del Amor y de su "impotencia" total como amor. Esta "debilidad" de Dios, este oscurecimiento, ofrece al ser humano el espacio de libertad necesaria a su respuesta de amor" (Quoist).

Si la fe se reduce a pedir y a vivir rituales que ofrecen al creyente satisfacciones sentimentales y que lo hacen "creer" que Dios le hará caso (lo oirá y le dará la respuesta que él quiere), estará más cerca de posiciones esotéricas que de la fe que permite descubrir la verdadera e infinita ternura de Dios, ternura que Él quiere, por nuestro medio, hacer llegar a todos los hermanos y hermanas.

Esperar soluciones milagrosas para todo, sin poner nuestro empeño, voluntad y trabajo para mejorarnos y mejorar nuestro medio y para acertar en soluciones que permitan superar problemas, devela que la imagen que se tiene de Dios se acerca más a la de un mago, que a la de un verdadero amante, es olvidar; o no saber nunca que la gracia es el amor con que Cristo nos ama y que cuando este amor nos toca nos transforma, como sólo el amor transforma, crea y recrea al amado (a). - Gracia, nada más lejana del milagrerismo restaurador de baches y paliativo de problemas y penas individuales! A pesar de lo lejano, de las indulgencias, del verdadero espíritu cristiano del amor y la esperanza, es preciso recordar que el Papa Pío IX, el 2 de marzo de 1862 concedió, a perpetuidad, una indulgencia plenaria a los fieles que visiten la Iglesia de los Ángeles el 2 de agosto. Este hecho nos vuelve a las acciones de la Iglesia medieval, con todo lo falaz que resulta a la luz del Evangelio de Jesús y demuestra lo complejo y ambiguo de la devoción: cómo ella se acerca a ratos a la verdadera fe y cómo se aleja de ella, algunas veces, a instancias de la misma iglesia oficial.

\section{¿Manipulación por 300 años?}

Desde lo que hemos visto y leído nos queda el dolor de haber 
descubierto que el clero ha orientado por 300 años esta devoción y ha sacado de ella prestigio, recursos económicos y fuerza social. Además los políticos han utilizado su imagen para dar sus propios mensajes intencionados.

Los devotos y devotas, por su parte, no han contado nunca con una fe popular educada para descubrir el Amor liberador de Dios, en la historia personal y nacional. A pesar de los cambios teológicos y pastorales impulsados por el Concilio Ecuménico Vaticano II, la devoción no ha sufrido transformaciones profundas.

Pareciera que la orientación que la Iglesia Católica de Costa Rica le ha dado está más cerca del folklore y de la religiosidad popular anquilosada en creencias de tipo mágico, al servicio de los mitos históricos nacionales, que al mensaje liberador del Evangelio.

Han convertido a La Negrita en un mito más al servicio de posiciones políticas (princesa de la paz, medio para alcanzar la concordia entre los costarricenses). Sentimos la imperiosa necesidad de rescatar en esta devoción el sentido de Dios Amor y de lo transcendente del Evangelio de Jesús. La integralidad de su mensaje nos lleva, no a buscar remedios, sino a curar al "enfermo completo."

No dudamos que en los actos de fe de los devotos y devotas, y de sus celebraciones multitudinarias, Dios se revele y que a través de María prodiga bienes y paz a sus hijos e hijas, Él es el Misericordioso por excelencia pero ello no nos exime como miembros de la Iglesia, de manifestar todo lo que nos aleja del verdadero Dios Vivo y de ayudar a nuestros hermanos y hermanas a liberarse de creyencerías.

Desventuradamente, el testimonio de esta devoción popular carece de calidad profética. Sin embargo, debidamente evangelizada la devoción a La Negrita, podría ejercer el papel bíblico del "resto", dada su especialidad en nuestra vida cristiana. Hoy, a la luz de la dignificación de la mujer que se pelea como derecho, en todo el mundo, es preciso que el mensaje de mujer subyugada, expresado en las formas indígenas de la imagen y en su color negro de identificación con las mujeres de las etnias que han sido tenidas por esclavas, en el patriarcalismo blanco occidental, se fortalezca y actualice.

Es preciso, también, que el mensaje liberador para las mujeres expresado tanto en la vida y acciones de Jesús, como en las aportaciones del discurso cristiano de igualdad en dignidad humana de los varones y de las mujeres, se convierta en realidad. En los discursos del magisterio de la Iglesia se ha hecho una alta valoración de la persona humana, desde la ley del amor fraterno como hijas e hijos de Dios y miembros de la Iglesia pero estos criterios y 
principios se han aplicado muy lentamente en la Iglesia costarricense y han sido adulterados, ideológicamente, tanto por iglesias particulares, como por movimientos, grupos y personas que le temen al sentido liberador del Evangelio.

Además, el peso de la historia y su inercia y pasividad, unidas al egoísmo privilegiado y prepotente del varón, han hecho creer, dentro de la Iglesia, que es suficiente con variar unas cuantas costumbres sociales que permitan un cambio cosmético en la dignificación de las mujeres y en sus relaciones con los hombres.

Las devotas de La Negrita le pedimos que con su fuerza y claridad, nos ayude a romper con la dominación y sometimiento patriarcales, tanto dentro como fuera de la Iglesia, para convertirnos, así, en protagonistas en paridad y colaboración con los varones, en todos los campos de la vida.

\section{Bibliografía}

Ayala, Vidal, Con María en Oración. PS editorial, Covarrubias, 19. Madrid. Segunda edición, 1984.

Biblia de Estudio, Dios habla hoy. Sociedades Bíblicas Unidas. Tercera edición, 1994.

Boff, Leonardo, El rostro materno de Dios. Ediciones Paulinas. Cuarta edición, 1979.
Boff, Leonardo, Encarnación: la humanidad y la jovialidad de nuestro Dios. Editorial Sal Terrae, Santander, España. Segunda edición, 1978.

Camblin, José. Notas Teológicas sobre el lenguaje popular. S.F., S.F.

Campos, Luis y otros. Pastoral y Lenguaie. CELAM. Talleres Ediciones Paulinas, Bogotá, Colombia, 1973.

Chase Brenes, Alfonso, Nuestra Señora de los Ángeles. Primera ed. San José: Editorial Costa Rica, 1995.

de Mello, Anthony, Caminar Sobre las Aguas. Editorial LUMEN, Buenos Aires, República Argentina, 1993.

Eschenbach, Úrsula, La mujer, un ser desconcertante? Ediciones Sígueme, Salamanca, España, 1968.

Galilea, Segundo, El reino de Dios y la liberación del hombre. Ediciones Paulinas, Bogotá, Colombia, 1985.

González Ruiz, José María, Creer es comprometerse. Ediciones Marova Editorial Fontanella, España. Quinta edición,1974.

Küng, Hans, Proyecto de una ética mundial, Editorial Trotta S.A. 1991.

Küng, Hans, 24 Tesis sobre el problema de Dios. Ediciones Cristiandad, Madrid, España. 1981.

Mardones, José María, Para comprender las nuevas formas de la religión, la reconfiguración poscristiana de la religión, Editorial Verbo Divino, España, 1994. 
Marzal, Manuel. Investigación e hipótesis sobre la religiosidad popular. CELAM. Quito, Ecuador, 1973.

Quoist, Michel, A corazón abierto. Ediciones Sígueme-Salamanca, España. Tercera edición, 1985.

Radford Ruether, Rosemary, Maria: el rostro femenino de la Iglesia, art. en Del cielo a la tierra Una Antología de Teología feminista.
Sello azul, Editorial de Mujeres, Santiago, Chile, $1^{\text {ra }}$ edición pág. 149, 1994.

Strauss Levi. Antropología Estructural. Paidós. Barcelona, 1995.

Vaticano II, Documentos completos. Librería Parroquia), México, Quinta edición. 1982.

Vidales, Raúl. Pastoral y Lenguaje. S.E., Quito, Ecuador, 1973. 

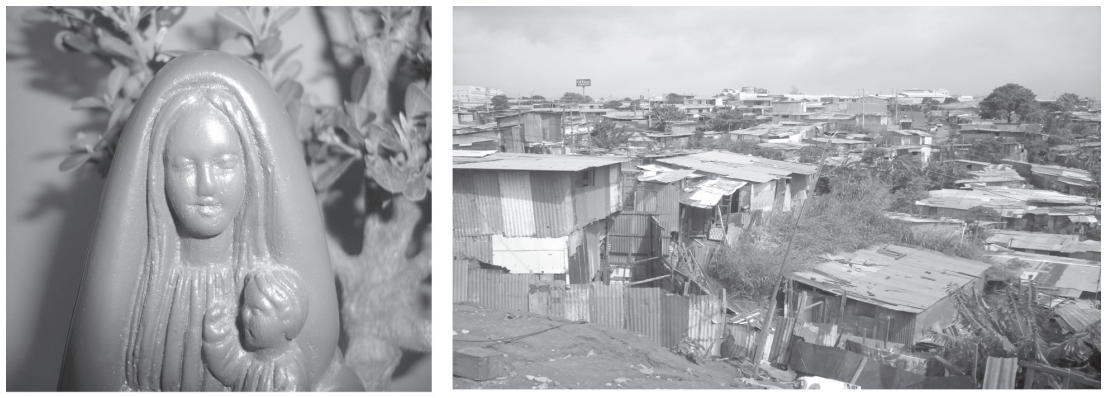

Los pobres de Guararí, Heredia, colindando con el Paseo de las Flores.

La Virgen de los pobres
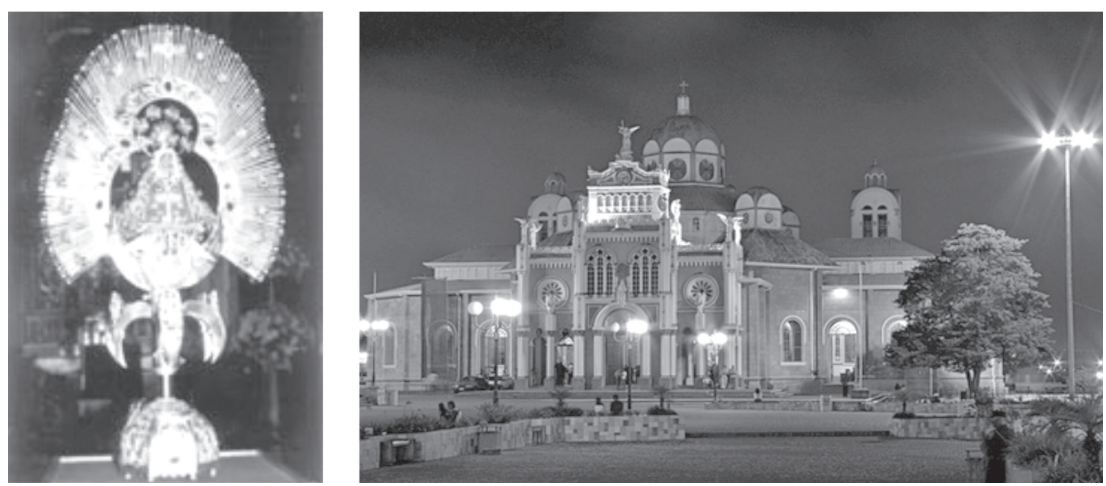

¿Quién piensa en ellos ? - Jesús de Nazareth.

"Venid benditos de mi padre, porque tuve hambre y me disteis de comer".

La Virgen del poder religioso mercantil 